Universidad de Lima

Facultad de Comunicación

Carrera de Comunicación

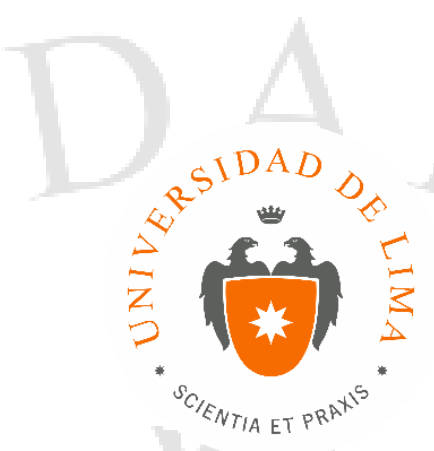

\title{
LA PRODUCCIÓN DE CONTENIDOS DIGITALES PARA EL BLOG DE TECNOLOGÍA SYNC.PE
}

Trabajo de Suficiencia Profesional para optar el Título Profesional de Licenciado en

Comunicación

Ernesto Vergara Flores

Código: 20021547

Asesora:

Beatriz Muñiz

Lima - Perú

Marzo 2017 


\section{LA PRODUCCIÓN DE CONTENIDOS DIGITALES PARA EL BLOG DE TECNOLOGÍA SYNC.PE}




\section{Tabla de contenidos}

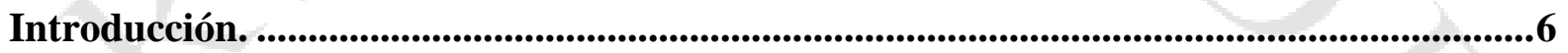

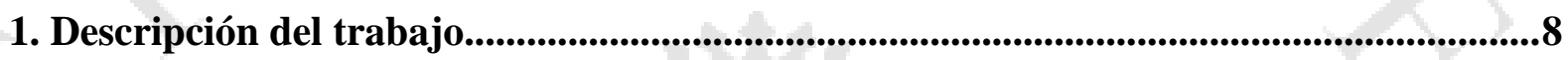

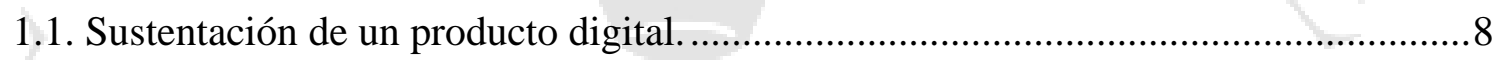

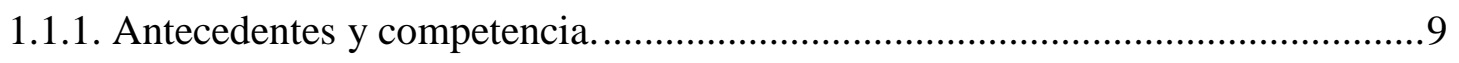

1.1.2. Organización: equipo de redacción y cargos. ..................................................10

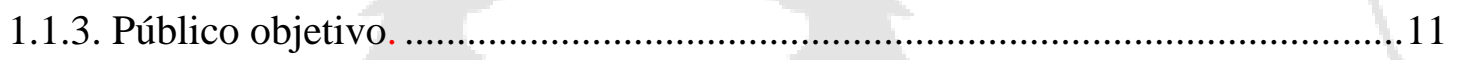

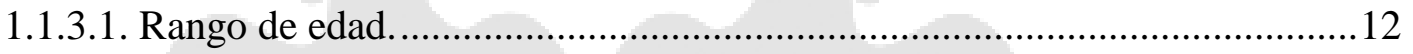

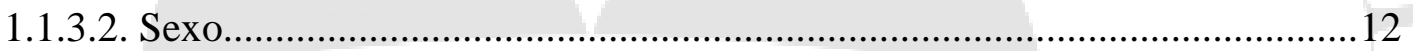

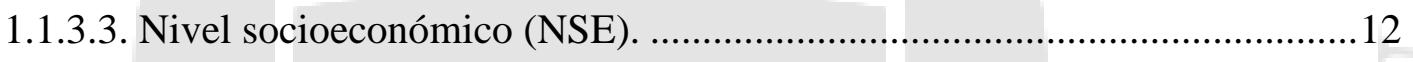

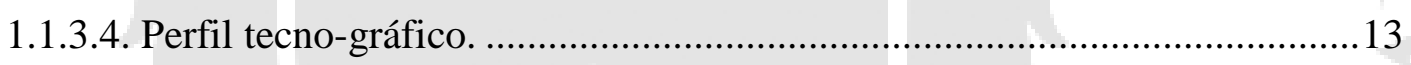

1.1.3.5. Características clave de usuario de Sync.Pe. ............................................ 16

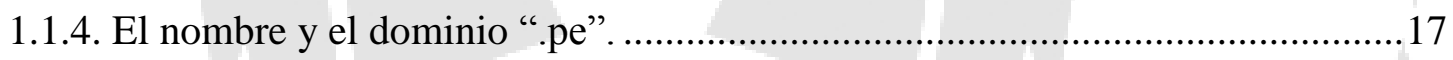

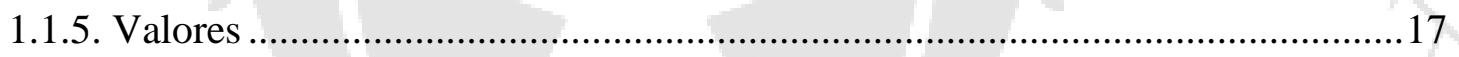

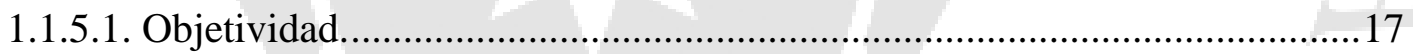

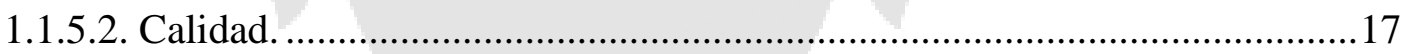

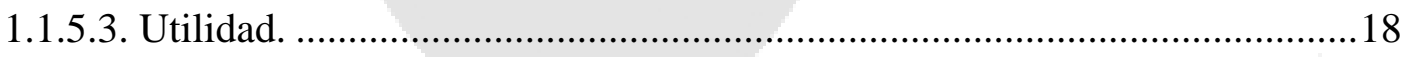

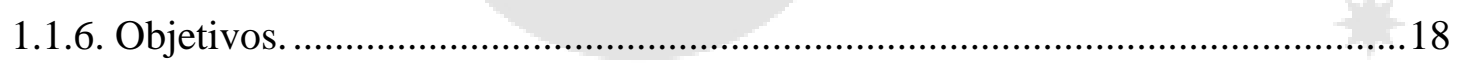

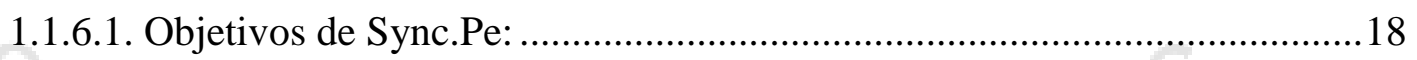

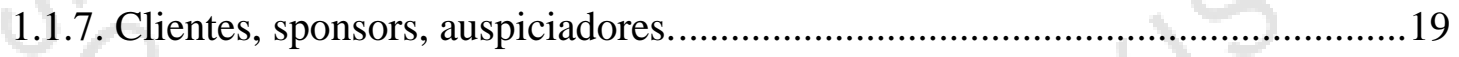

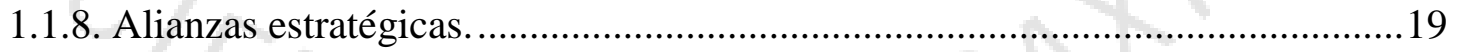

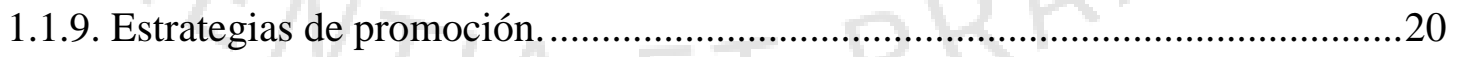

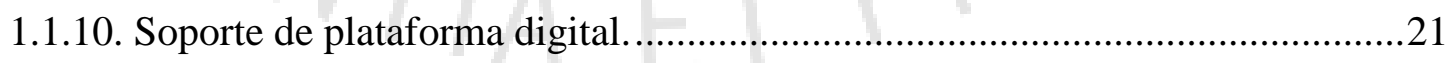

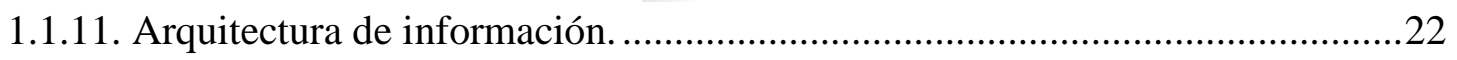

1.1.12. Identidad gráfica: diseño de contenidos y página web. .................................23

1.1.13. Tono de comunicación y estilo. ....................................................................29

1.1.14. Estrategias de contenido. ............................................................................ 30 
1.1.15. La producción y definición de tipos de contenido.

1.1.15.1. Sobre los textos.

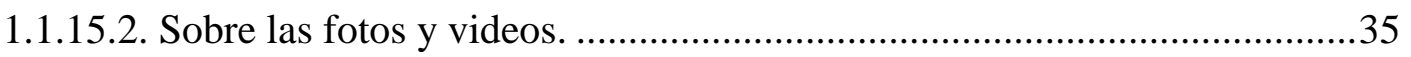

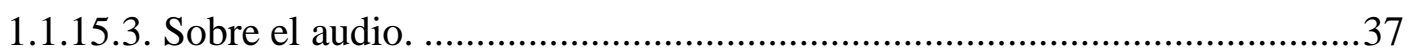

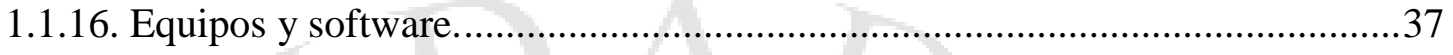

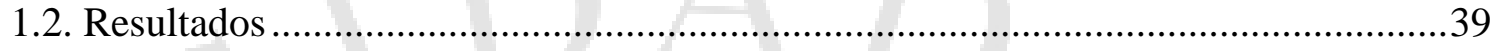

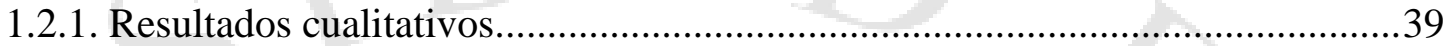

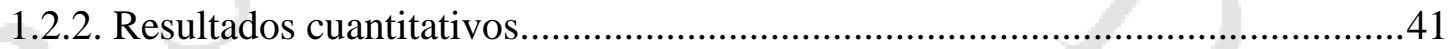

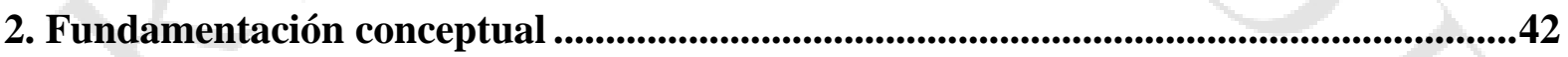

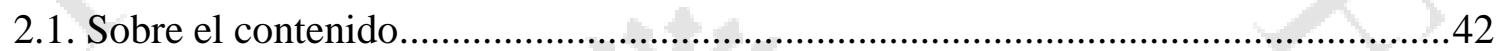

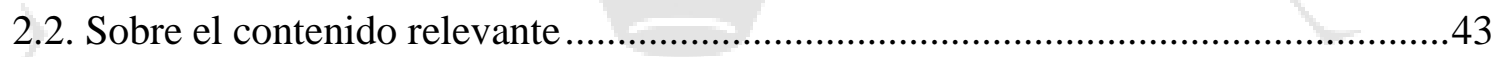

2.3. Sobre la producción de contenido relevante ….........................................................43

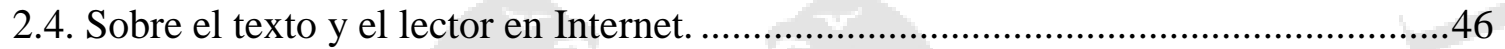

2.5. Sobre los contenidos gráficos y audiovisuales........................................................49

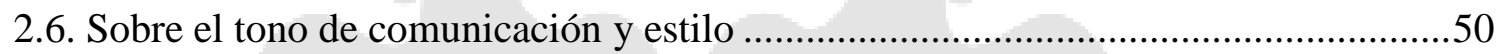

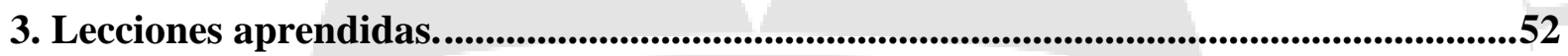

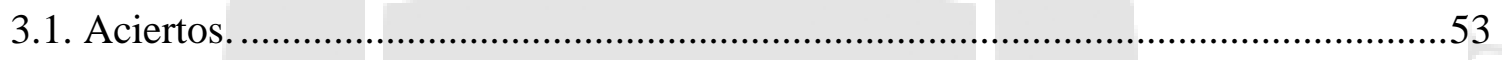

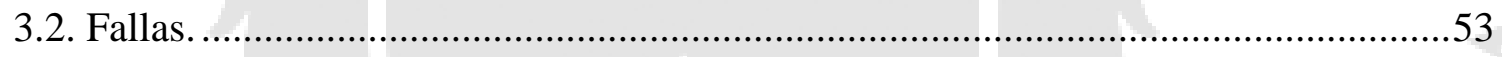

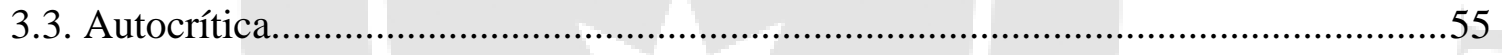

3.3.1. Establecer, desde un comienzo, objetivos fundamentados. .............................55

3.3.2. Plantear nuevos objetivos a partir de los ya alcanzados: ..................................56

3.3.3. La importancia de un calendario editorial. ...................................................56

3.3.4. La importancia de una estrategia de promoción en redes sociales. ....................57

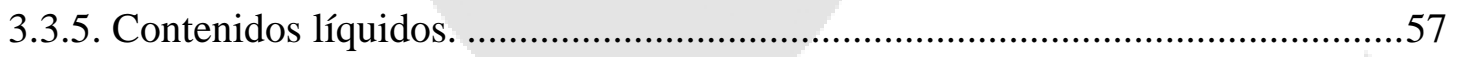

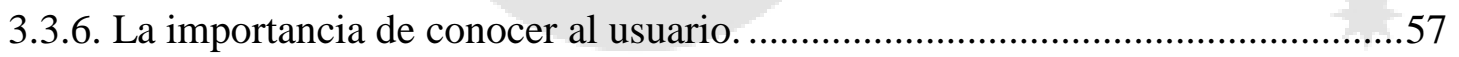

3.3.7. La importancia de los medios tradicionales....................................................58

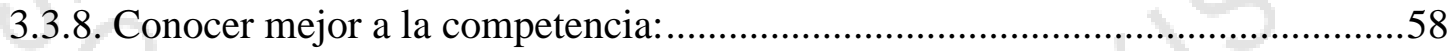

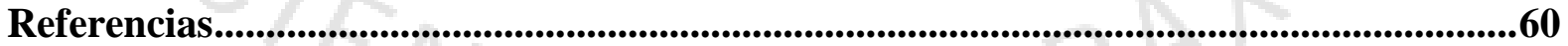




\section{Introducción.}

Sync.Pe fue un blog de tecnología lanzado a mediados de 2013 por Ernesto Vergara y Eduardo Ojeda. El motivo de crear el site fue alentado por tres factores. Primero, los dispositivos electrónicos habían llegado a un punto de popularidad jamás alcanzado. El iPod, las consolas de videojuegos, los teléfonos inteligentes, y sistemas operativos como iOS y Android, acercaron la tecnología a más personas, al ofrecer interfaces amigables para el usuario común, así como precios más accesibles. Marcas como Apple, Samsung, Sony, LG y Google, entre otras, iniciaron una guerra nunca antes vista por la atención y preferencia de un público cada vez más amplio. Por eso mismo, los blogs dedicados a las reseñas de dispositivos electrónicos se volvieron fundamentales para usuarios que, no solo querían conocer más sobre nuevos productos disponibles en el mercado, sino también ser ayudados en la elección de compra del más adecuado a sus necesidades y presupuestos; lo que creó una gran oportunidad para nuevos medios digitales basados en tecnología como Sync.Pe.

Por otro lado, si bien existían blogs locales basados en las reseñas de productos electrónicos, la mayoría solo presentaba publicaciones básicas e informativas, pero sin mucho cuidado en la calidad de los textos, las fotografías y lo audiovisual. Esto abrió otra oportunidad para que un site local de destaque a partir de contenidos relevantes y visualmente atractivos.

Por último, y en relación con lo anterior, la creación de Sync.Pe fue inspirada por The Verge, un medio digital sobre tecnología cuyo lanzamiento en 2011 refundó la visión que se tenía sobre la producción de contenidos digitales. La calidad de las fotografías, textos, y videos que esta web ofreció desde sus inicios fue muy superior al resto, y en poco tiempo, la página se convirtió en la más importante de su segmento, superando a clásicos como Engadget, Gizmodo y hasta Wired.

De esta forma, Sync.Pe tuvo como objetivo convertirse en un medio fundamental entre los amantes de la tecnología en el Perú, basándose en la calidad de sus publicaciones para lograrlo. Además del respaldo del público, la web también tuvo como objetivo contar con el apoyo y reconocimiento de marcas productoras de smartphones, tablets, laptops y otros 
dispositivos electrónicos; y así, contar con dispositivos para generar reseñas de productos dirigidas a usuarios que, no solo sean capaces de valorar la calidad de los contenidos que Sync.Pe ofrecería, sino también pudieran confiar en la independencia del site sobre los intereses de estas compañías tecnológicas.

En el siguiente trabajo de suficiencia profesional se explicarán, además de cómo fueron producidas las publicaciones de Sync.Pe, los resultados conseguidos por la página web desde su lanzamiento en 2013 hasta su cierre a comienzos de 2016; ademas de los logros que los creadores de ésta consiguieron en paralelo gracias al prestigio conseguido por la calidad de los textos, fotos, videos y otros elementos de la comunicación ofrecidos en el site.

Finalmente, se expondrán los aciertos y fallas en la planificación de contenidos, diseño web y promoción digital. Además, se explicarán medidas que pudieron haberse utilizado, no solo para que la web continúe operando, sino para conseguir las metas que no pudieron conseguirse. 


\section{Descripción del trabajo.}

\subsection{Sustentación de un producto digital.}

Se eligió un modelo base de sustentación de un producto o proyecto digital construido a partir del método Lean UX, que suele utilizarse en el emprendimiento digital. Para su creador, Jeff Gothelf (2012), esta metodología simplifica la creación de productos digitales estableciendo parámetros simples de entender y de formular, y así, acelerar el desarrollo de estos.

Para la sustentación de Sync.Pe como proyecto de medio digital se creó el siguiente modelo a completar:

- Antecedentes y competencia.

- Organización: equipo de redacción y cargos.

- Público objetivo: rango de edad, sexo, nivel socioeconómico, perfil tecno-gráfico, perfil del usuario de Sync.Pe.

- Nombre: concepto, dominio.

- Valores.

- Objetivos: primarios, secundarios, indicadores de desempeño, métricas.

- Clientes, sponsors, auspiciadores.

- Alianzas estratégicas.

- Soporte de plataforma digital.

- Arquitectura de información: contenidos y mapa de sitio.

- Identidad gráfica.

- Tono de comunicación.

- Estrategias de promoción.

- Producción y tipos de contenido.

- Equipos utlizados para la producción de contenido. 


\subsubsection{Antecedentes y competencia.}

A finales del 2011 se produjo un hecho que cambió cómo se configurarían los blogs y las páginas web de tecnología alrededor del mundo. El lanzamiento de The Verge en noviembre de ese año demostró que, a diferencia de lo que el público esperaba de estas publicaciones, los contenidos generados por estas podían llegar con una calidad que hasta ese momento solo era atribuida a la televisión y a los medios digitales con mayor presupuesto.

The Verge, parte del conglomerado VOX Media, apostó por un diseño web atractivo, que se separaba de la típica diagramación de los blogs tradicionales donde los posts se ordenaban por una lista vertical. Los textos, las fotografías y los videos eran de una calidad jamás vista en este tipo de publicación. El tono de comunicación también era distinto: un lenguaje más sencillo para un público que no necesariamente era fanático de la tecnología, sino que comenzaba a serlo gracias al impresionante avance de los dispositivos móviles. La clave, sin duda alguna, fue entender que la tecnología ya no estaba enfocada en un nicho de mercado, sino que ahora estaba disponible para una cantidad mucho más grande de personas alrededor del planeta. Si la tecnología se había vuelto más amigable, entonces las publicaciones y los medios especializados en ella tenían que entregar contenidos acordes con esta nueva tendencia. Así fue como The Verge, en apenas un año, se convirtió en la página de tecnología a consultar, y clásicos como Engadget y Gizmodo tuvieron que alinear sus contenidos e invertir en mejor producción.

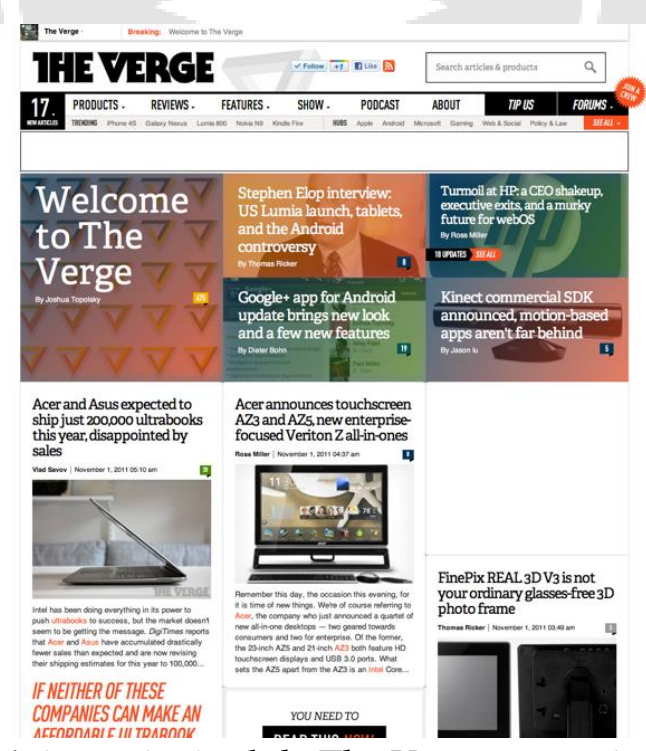

Imagen 1. Página principal de The Verge en noviembre de 2011 
En el Perú los blogs de tecnología ya llevaban algunos años en la red. Arturo Goga fue uno de los primeros bloggers en llegar a una buena cantidad de público, mientras que Tecnología21 y Perusmart se presentaron como alternativas que, si bien eran blogs en sí mismos, se presentaban como páginas webs dedicadas al tema. Para el 2013 estos medios contaban con un gran número de seguidores, y participaban en coberturas de eventos locales, realizaban reseñas de dispositivos que se venderían próximamente en el mercado y eran considerados influencers entre los fanáticos de la tecnología en el país.

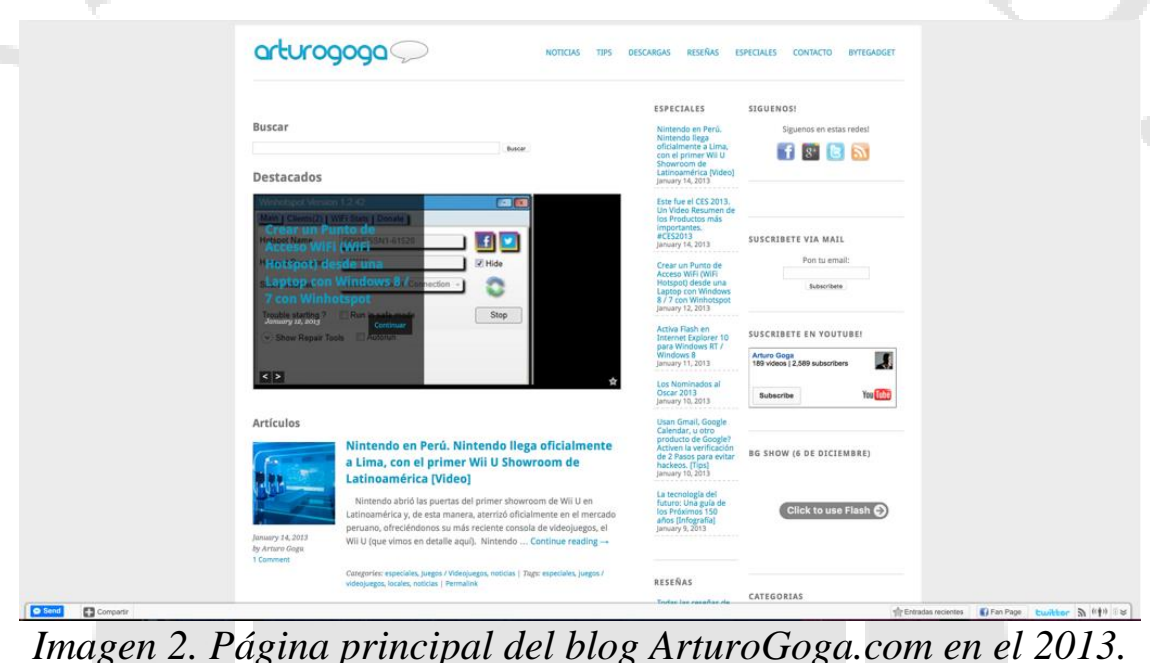

Pero así como en EEUU de 2011, previo al lanzamiento de The Verge, los blogs y páginas locales de tecnología no contaban con contenidos que destacaran de lo que se hacía en el exterior. De hecho, algunos textos eran muy extensos para la web, algunos contaban con faltas de ortografía y de redacción, las fotos y los videos tenían un acabado amateur y la calidad de los contenidos en sí dejaban mucho que desear. Es en este contexto donde se presenta una oportunidad para Sync.Pe, cuya estrategia es destacarse a partir de la calidad de sus contenidos.

\subsubsection{Organización: equipo de redacción y cargos.}

El proyecto fue fundado por dos comunicadores, Ernesto Vergara y Eduardo Ojeda. Se establecieron dos áreas de trabajo: la logística y la creativa. Ojeda se encargaría de la primera, que constaba de comprar el dominio, el hosting y la instalación del sistema CMS elegido para crear el blog. Además de crear las cuentas de correo, las de redes sociales, YouTube, RSS y activar cualquier tipo de plataforma digital relacionada con el proyecto. Por otro lado, también sería su responsabilidad el contacto con marcas y potenciales clientes. Así como las estrategias de promoción tanto en buscadores como en Facebook. 
El área creativa le fue encargada a Ernesto Vergara, cuyas responsabilidades eran las de crear una estrategia de diseño y producción de contenidos, la realización de reglas de producción de texto, fotos, gráficos y elementos audiovisuales, la construcción de la página web así como la identidad visual, además de la realización de las piezas de contenido. Por otro lado la configuración de un estilo y tono de comunicación del site, así como también la edición de textos, fotos y videos propios y creados por redactores asociados al blog.

\subsubsection{Público objetivo.}

Se trata de personas entusiastas de la tecnología, en especial de los dispositivos de computación estacionarios, móviles y conectados al Internet. Es un público que creció durante la popularización de las computadoras personales, los primeros celulares y consolas de juegos de video. Son usuarios que han seguido los avances de marcas tecnológicas importantes y hasta han tomado partido por una de ellas. Buscan tener información confiable y exacta sobre nuevos dispositivos, software, y el uso que se les puede dar a esto y cómo influenciarán en sus vidas. Se consideran, además, como personas a los que sus amigos y familiares confían en el momento de tomar una decisión de compra sobre algún dispositivo, programa o juego de video, dada la cantidad de información que tienen sobre tecnología. Ellos mismos suelen consultar en blogs, webs y canales de YouTube sobre nuevos lanzamientos, reseñas de productos y les gusta aprender las mejores formas de cómo aprovechar aún mejor sus gadgets.

Por otro lado, se trata de un público que aprecia la confianza que le ofrece un medio digital, sobre todo cuando se trata de recomendar productos y aplicaciones, ya que a ellos mismos les gusta que quienes los rodean confíen en ellos en el momento de escuchar sus recomendaciones. Son personas que han logrado una reputación de tener un amplio conocimiento sobre tecnología y todo lo que ésta rodea, es por es que siempre preferirán y consultarán los medios que les den la información más certera y sin ningún tipo de interés adicional con marcas o auspiciadores.

Se investigó al público objetivo a partir de 10 estudios de IPSOS Apoyo desarrollados entre el 2012 y 2013:

- Hábitos y actitudes hacia la prensa escrita (2013).

- Hábitos y actitudes hacia los medios publicitarios alternativos (2012). 
- Perfil del adulto joven (2013).

- Perfil del "celunauta" (2013).

- Perfil de "internauta” limeño (2013).

- Perfil del "smartphonero" (2013).

- Perfil del usuario de redes sociales (2013).

- Uso y actitudes hacia Internet (2013).

- Uso y actitudes hacia la telefonía móvil (2013).

- Web y redes sociales en empresas (2013).

La información de estos estudios ayudó a establecer al público objetivo al que había que apuntar los contenidos de Sync.Pe, además de la elección de las plataformas y redes sociales en las que el proyecto se apoyaría para llegar de una forma más directa a este tipo de usuario de Internet.

\subsubsection{Rango de edad.}

Se establecieron dos rangos de edad para los usuarios promedio de Sync.Pe: de 18 a 24 años y de 25 a 35 años. Según los estudios de IPSOS Apoyo sobre el perfil del adulto joven (2013), el "celunauta" (2013), "internauta" limeño (2013), el "smartphonero" (2013) y del usuario de redes sociales (2013); estos dos rangos contienen al grueso de usuarios de Internet en Lima así como en el resto del país. Una buena porción de ellos contaba con un celular inteligente, así como también una cuenta en alguna red social, en especial, en Facebook. Además, es en ambos rangos de edad donde existen usuarios que buscan información en Internet previa antes de realizar una compra importante.

\subsubsection{Sexo.}

Los estudios de IPSOS Apoyo declaraban que los usuarios de smartphones eran en la mayoría de sexo masculino: $20.3 \%$ contra un $16.1 \%$ de un total de 3'078,837 de personas con un teléfono inteligente; y en cuanto al uso de Internet en general, eran también los hombres quienes dominaban el acceso: $71 \%$ contra $61 \%$ de un universo de 11,294,000. Es por eso que el usuario promedio de Sync.Pe fue definido como un hombre de 18 a 35 años de edad.

\subsubsection{Nivel socioeconómico (NSE).}

Se estableció que el usuario de Sync.Pe estuviese en la combinación de sectores A y B de nivel socioeconómico. Según los estudios de IPSOS Apoyo en Uso y actitudes hacia Internet (2013), estos dos niveles cuentan con la mayor cantidad de usuarios conectados a la red, además de ser los que más acceden a esta. De hecho, el NSE A se conectaba en promedio 
27 veces al mes a Internet, mientras que los usuarios del NSE B lo hacían 22.6 veces en el mismo rango de tiempo.

Otros datos que se tuvieron en cuenta fueron que tanto los usuarios de Internet de los segmentos A y B eran más activos dentro de sus conexiones a la red. El NSE A congregaba a un $93 \%$ de usuarios que contaba con una red social, mientras que el mismo porcentaje también existía en el NSE B.

La visita y consulta a blogs también era importante en el NSE A, con un 76\% de usuarios que acudían a ellos, mientras que en el NSE era el 60\% de ellos los que preferían este tipo de sites. De esta forma el usuario promedio de Sync.Pe sería un hombre de entre 18 a 35 años de edad del NSE A o B.

\subsubsection{Perfil tecno-gráfico.}

Para el 2013 el acceso a Internet en casa había ascendido de un 45\% en 2011 a un $56 \%$ de los 11,294,000 de internautas en el Perú urbano. En el NSE A el 92\% se conectaba desde el hogar, mientras que en el NSE era 91\% que contaba con este servicio en casa.

IPSOS Apoyo en su estudio "Perfil del internauta limeño" (2013) define a tres tipos de usuarios de Internet: el "cabinero", el "hogareño" y el "institucional”. En el caso de Sync.Pe como proyecto digital en construcción, se prefirió tomar en cuenta al segundo y tercer grupo, es decir, los que tenían acceso a la red desde sus propias casas, así como desde sus centros de estudio y laborales.

A diferencia del "cabinero", cuyo 33\% se conectaba a la red de 3 veces o más por semana, el "hogareño" contaba con un $77 \%$ de usuarios que superaban este número de conexiones semanales, mientras que el "institucional" contaba con un $83 \%$ de usuarios que navegaban la web, accedían a redes sociales y se comunicaban vía chat más de 3 veces cada 7 días.

En cuanto a la preferencia por blogs, solo el $29 \%$ de "cabineros" acudían a ellos. En cuanto a los "institucionales" este porcentaje subía a un $31 \%$, pero entre los usuarios "hogareños" el acceso a este tipo de medios digitales se disparaba a un 59\%.

Sobre la presencia en redes sociales, los "cabineros" contaban con un $70 \%$ de usuarios con una cuenta en alguna de ellas, mientras que el $91 \%$ de "hogareños" y el $88 \%$ de “institucionales" se conectaba a una. Estos datos definieron aún más al usuario promedio de Sync.Pe, que accedería al blog tanto desde sus casas como desde sus lugares de estudio y trabajo, pero no desde cabinas de Internet. De hecho, según el estudio "Uso y actitudes hacia Internet" (2013) de IPSOS Apoyo, la asistencia a cabinas de Internet disminuyó de un 62\% en 
2011 a un 46\% en 2013; mientras que el acceso desde la casa aumentó de un 45\% en 2011 a un 56\% en 2013. La tendencia de una mayor penetración de Internet en el hogar estaba clara, así como la caída en el acceso desde cabinas públicas.

Además de estos tres perfiles, IPSOS Apoyo establece tres perfiles más basados en el acceso mensual a Internet: el usuario ocasional, moderado e intensivo. De estos, el proyecto se inclinó en el usuario intensivo de Internet, el cual ingresaba a la red como mínimo 3 veces por semana.

El usuario intensivo, de hecho, no solo se conectaba más veces a la red que el resto, sino que era más activo en sus conexiones. Es decir que a diferencia del 53\% de "ocasionales" y del 72\% de "moderados", el 94\% de "intensivos" participaba dentro de una red social. Además, el 25\% de estos últimos contaba con una cuenta en YouTube, mientras solo el $8 \%$ de "moderados" y el 1\% de "ocasionales" estaba inscrito en esta plataforma. Sobre el acceso a blogs en Internet, los usuarios "intensivos" dominaban el ingreso a este tipo de sitios por un $59 \%$.

Por otro lado, en el 2013 la penetración de los smartphones se consolidó, en especial para los que vivían en territorios urbanos. Según el estudio Perfil del smartphonero (2013), de un total de 3'078,837 poseedores de un teléfono inteligente, el 30\% de este universo tenía entre 18 a 24 años, y un $22 \%$ cubría el rango de edad de 25 a 39 años. En cuanto al nivel socioeconómico, el $60 \%$ de personas del segmento A poseían uno, mientras que el $42 \%$ de personas del segmento B eran usuarios de un teléfono inteligente. Además, resultó importante la información que IPSOS Apoyo encontró sobre los usos que los peruanos les daban a los smartphones, entre ellos:

- El 89\% de universo usaba su smartphone en conjunto con otro dispositivo electrónico: laptop, TV, SmartTV, radio, PC de escritorio, etc.

- El uso del smartphone ya había ocupado espacios donde antes los celulares no aparecían: reuniones con amigos y familiares, en el trabajo, mientras se ve televisión, durante alguna o todas las comidas del día, durante los traslados tanto en auto propio como en transporte público e incluso en el baño.

- Del universo de 3’078,837 personas, el 65\% usaba los teléfonos inteligentes para ingresar a Facebook, el 40\% para navegar en la web, el 34\% para ingresar a Twitter y el 22\% para leer diarios y enterarse de noticias. La aplicación más usada era Facebook. 
- Para el usuario de smartphone promedio del Perú urbano, estos dispositivos le otorgaban dos valores muy importantes: conectarse con las personas que más quieren y enterarse primero de las noticias.

Si bien realizar llamadas era el principal uso que le daba un usuario a su smartphone (82\% del universo), ingresar a redes sociales desde estos dispositivos se volvía cada vez más popular (52\% del total de usuarios). Pero quizás uno de los hallazgos más importantes de este estudio es que ya para el 2013, los usuarios de un teléfono inteligente preferían navegar en la web en uno de estos dispositivos (40\%), más que en una laptop o PC de escritorio (26\%). Esto dejaba claro una tendencia que ya se había percibido en años anteriores, y que a la fecha, solo se ha incrementado: que el usuario promedio de Internet se conecte a la red ya no desde una computadora, sino desde un teléfono inteligente que puede llevar a todas partes.

Además, en cuanto al uso de redes sociales desde un smartphone, se percibió un cambio importante en cuanto al comportamiento del usuario en relación a compartir enlaces, publicaciones y cualquier otro contenido producido por un medio digital. De hecho, en 2012 el $27 \%$ de usuarios de teléfonos inteligentes compartieron piezas de contenido entre sus amigos y seguidores, mientras que en 2013 el porcentaje se incrementó al 35\% de poseedores de un smartphone.

Sobre el acceso específico a blogs, el estudio "Uso y actitudes hacia internet" de 2013 por IPSOS Apoyo arroja datos que fueron de mucha importancia previa a la creación de Sync.Pe como medio digital. Según la investigación en 2013, el 46\% de usuarios de Internet encuestados conocían de los blogs. Dentro del NSE A, el 75\% de personas dentro de este segmento tenían conocimiento sobre este tipo de medios digitales, mientras que en el sector $\mathrm{B}$ el $63 \%$ de usuarios sabían de la existencia de estos.

En cuanto a edades, el 53\% del rango de 12 a 17 años conocía los blogs, mientras que el $61 \%$ de personas del rango de 18 a 24 habían escuchado sobre ellos, así como el 45\% de los encuestados entre los 25 a 35 años. De todos modos, el conocimiento general sobre los blogs no era muy arraigado. Según IPSOS, en 2013 solo el $25 \%$ de usuarios de Internet había visitado un blog, mientras que un $21 \%$ jamás lo había hecho. A comparación de esos porcentajes, el $54 \%$ de usuarios no sabían de ellos.

En cuanto a los temas más buscados dentro de los blogs, el 28\% accedía a ellos intentando encontrar información académica, un 25\% buscaba música y un $21 \%$ deportes. Sobre la frecuencia, solo el 3\% acudía a un blog todos los días, mientras que el 14\% lo hacía cada dos o tres días y un $26 \%$ cada semana. 
IPSOS Apoyo también encontró datos sobre las actividades que el universo de usuarios conectados hacían en Internet. Precisamente sobre la búsqueda de información y noticias, la investigación declara que el tanto el 77\% de personas del NSE A entraban a Internet para buscar información que los ayudara en sus estudios, trabajo y vida diaria, mientras que un $68 \%$ del NSE B quería lo mismo. Sobre leer noticias en Internet y mantenerse enterado de los temas de interés, el 79\% de NSE A y el 55\% del NSE B preferían la red.

Sobre el uso de navegadores, el 73\% del universo de usuarios de Internet prefería Google Chrome para navegar en la red, comparado con el 17\% de Microsoft Explorer y el 5\% de Firefox.

\subsubsection{Características clave de usuario de Sync.Pe.}

Al cruzar los datos definidos por los estudios de IPSOS Apoyo, el usuario de Sync.Pe cuenta con las siguientes características:

- Edad: 26 años aproximadamente.

- Sexo: Masculino.

- Ocupación: estudiante, trabajador dependiente o independiente.

- Nivel socioeconómico: A y B.

- Ciudad: Lima.

- Acceso a Internet: Más de 3 veces por semana.

- Acceso a Internet desde: Casa, trabajo, universidad, smartphone.

- Cuenta con estos dispositivos: Smartphone, Laptop, PC de escritorio, tablet.

- Busca en Internet: Información que le ayude en el trabajo, estudios y para su vida en general.

- Usa el Internet para: Ocio, hablar con amigos y familiares, revisar redes sociales, escuchar música, ver videos, conseguir información y estar actualizado con los temas que más le interesan.

- Intereses particulares: Tecnología, juegos de video, cine, música, cómics, compras por Internet, redes sociales.

- Redes sociales en las que forma parte: Facebook, Twitter, Instagram.

- Nivel de actividad en redes sociales: intensiva. 


\subsubsection{El nombre y el dominio ".pe".}

Se eligió "Sync" como el nombre definitivo para el site. Si bien era un nombre en inglés, algo que podría alienar a muchos usuarios locales de Internet, aportó dos ventajas: tener una extensión corta de apenas 4 caracteres sin contar con el dominio. Como segunda ventaja, el termino era reconocible para los fanáticos de la tecnología, que en algún momento tuvo que sincronizar (sync) alguno de sus dispositivos con una PC, periférico o aplicación. Al no estar disponible el dominio "sync.com" se optó por el dominio "sync.pe" de la Red científica peruana.

Para que el dominio fuera más fácil de pronunciar e identificar de forma sonora, el site se presentó como "sync.pe" desde el inicio, y no solo como "sync". De este modo, si bien era imposible contar con un dominio “.com” que es mucho más reconocible por la gran mayoría de usuarios de Internet en el mundo, el nombre completo del blog incluía el dominio ".pe" para que la dirección de este sea siempre recordada.

\subsubsection{Valores}

Sync.Pe basó sus valores en tres principios fundamentales y totalmente enfocados en beneficiar al público objetivo: objetividad, calidad y utilidad.

\subsubsection{Objetividad.}

La independencia para un medio de tecnología es primordial. Los usuarios confían en los contenidos de una publicación para decidir compras que, muchas veces, cuestan meses de ahorros y generan mucha ilusión para el fanático de la tecnología. Las marcas bombardean a sus potenciales compradores con cientos de estímulos e información que, muchas veces, parece desordenada o simplemente como una trampa publicitaria. En un mercado donde los teléfonos inteligentes, las computadoras personales, las laptops y otros productos similares ofrecen capacidades muy distintas y una amplia variedad de precios, un blog confiable que sea capaz de ayudar a decidir entre un dispositivo u otro resulta indispensable. La credibilidad es la base de los contenidos de estas publicaciones, y en Sync.Pe fue el valor al que más prioridad se le dio.

\subsubsection{Calidad.}

Para Sync.Pe es importante que el usuario no solo cuente con información lo más objetiva posible, creada pensando en sus necesidades más que en lo que quiera promocionar cualquier empresa, sino que los contenidos hayan sido producidos con la mejor factura posible. 
El objetivo fue que los visitantes se sientan inspirados por los contenidos, que estos les parezcan atractivos y dignos de compartir entre sus amigos y seguidores de redes sociales. Que se trate de publicaciones que alimenten la reputación online de los usuarios como fanáticos de la tecnología, pero al mismo tiempo, como conocedores de páginas relevantes en Internet. Además, que se genere en ellos una consciencia crítica sobre la calidad que puede conseguir un medio de Internet, y así, elevar los estándares de lo que consume y exigir mejores contenidos en el resto de páginas que visita.

\subsubsection{Utilidad.}

Además del cuidado en la producción de contenidos, en Sync.Pe se estableció que cada publicación debía ser útil para el lector. Que encuentre en ellas la información que buscaba, pero de una manera sencilla de entender, entretenida y breve en lo posible. La meta es que el usuario de la web no pierda el tiempo, tanto en la navegación de esta como en la lectura de sus contenidos; que serían creados pensando en sus necesidades, además de ubicarse en las redes sociales y aplicaciones que suele consultar diariamente.

\subsubsection{Objetivos.}

Los objetivos se dividieron en dos intereses en particular: sobre el público y sobre las marcas. Estos objetivos, de todos modos, estuvieron anclados en la calidad de contenidos que la página podría ofrecer para llamar la atención de ambos. Es decir que, si bien son objetivos que funcionaron para guiar el site al éxito esperado, se trataba de metas que provinieron siempre de lo que se pretendía lograr con el contenido.

\subsubsection{Objetivos de Sync.Pe:}

El primer objetivo de la publicación fue conseguir un número no menor a tres mil visitantes únicos por mes. Para lograrlo se planificó crear cuatro piezas de contenido diarias en blog que cubrieran, en especial, las noticias más importantes del día, además de contenidos únicos en el site, como recomendaciones de nuevas aplicaciones, artículos de opinión y por lo menos una vez por semana alguna reseña de un producto tecnológico. Estos contenidos serían compartidos desde la página de Facebook de Sync.Pe, desde donde el público objetivo podría acceder también a estas publicaciones. Como KPIs (Indicadores clave de desempeño) se estableció concretar un promedio de cien visitantes únicos al día, que al mes equivalgan a los tres mil que se trazó por alcanzar. En Facebook se revisarían también la cantidad que los contenidos fueron compartidos por parte de los usuarios. Los datos se consultarían en Google 
Analytics (visitas a Sync.Pe) y el alcance en Facebook desde las mismas herramientas de medición que ofrece la red social.

El segundo objetivo de Sync.Pe fue formar parte del grupo de medios especializados con los que cuentan las principales marcas de tecnología del país. Se buscó establecer nexos con las agencias de relaciones públicas de estas marcas, tanto por medio de personas que tenían sus contactos, como también intentando contactarlos directamente por correo electrónico. Se mediría el éxito de este objetivo al conseguir el préstamo de dispositivos para generar reseñas y contenidos adicionales, así como también invitaciones a cubrir los eventos oficiales de la marca en el mercado local.

\subsubsection{Clientes, sponsors, auspiciadores.}

Si bien siempre son importantes para la subsistencia de cualquier medio, se prefirió no contar con ningún tipo de publicidad en la página. Esto ocurrió por dos motivos: conservar la independencia absoluta del site sobre cualquier interés sobre sus contenidos, además de no afectar la lectura y navegación por parte del usuario que, ya en 2013, utilizaba de todos modos bloqueadores de publicidad en sus navegadores de Internet.

\subsubsection{Alianzas estratégicas.}

Se establecieron vínculos con marcas como Ripley, Nikon, Canon, LG y Coca Cola. De estas alianzas, los que se produjeron con las primeras tres marcas estuvieron basados en la promoción de contenidos, más no con fines de lucro. En el caso de LG y Coca Cola, sí se estableció un intercambio de dinero por los servicios del blog, pero sin mellar la independencia de este. De esta forma, las alianzas con las siguientes marcas funcionaron así:

- Ripley: Creación de contenidos en video para la tienda virtual de Ripley. Las publicaciones serían firmadas por el blog y describirían los productos tecnológicos que la marca quisiera promocionar. Estos se ubicarían en las páginas de cada producto en específico a través de un vínculo directo al canal de Youtube de Sync.Pe. Los contenidos estarían firmados por el blog, que tendría el respaldo de la compañía para promocionar a Sync.Pe como un site de tecnología importante. 
- Nikon y Canon: Ambas marcas, por separado, encargaron contenidos en video que resaltara funciones específicas de sus cámaras. Como en el caso de Ripley, las publicaciones estarían alojadas en el canal de Youtube de Sync.Pe, pero promocionadas desde las páginas de Facebook y otras redes sociales de las compañías.

- LG: Se planificó la creación de una serie de tutoriales dirigidos a los compradores de televisores inteligentes de la marca. Estos contenidos no irían firmados por Sync.Pe, pero sí conservarían el estilo del site. Se acordaron pagos económicos por video y se elaboró un plan de realización. Lamentablemente LG desistió del proyecto por problemas de presupuesto.

- Coca Cola: La marca convocó a Sync.Pe para la realización de cápsulas de contenido en audio, basados en noticias, tips, reseñas y cualquier otro tipo de información que tuviera que ver con la tecnología. Cada una de estas piezas debía ser de tres minutos y se reproducirían durante la programación de la radio. Luego del éxito de estas publicaciones, Coca Cola le ofreció a Sync.Pe un espacio semanal para un programa en vivo.

\subsubsection{Estrategias de promoción.}

Se promocionaron los contenidos de Sync.Pe en Facebook y en Twitter, siendo la primera la red social en la que se concentró buena parte de los esfuerzos de esta estrategia.

Se estableció compartir cuatro enlaces en la página de Facebook de Sync.Pe durante el día:

- Uno en la mañana (9am): Notas informativas, rumores.

- Un segundo post al medio día: Reseñas, artículos, lanzamientos.

- Un tercer post en la tarde (3pm): Artículos como tips, comparaciones, etc.

- Un post final en la noche (8pm). Artículos.

Estos horarios fueron definidos a partir de la información de visitas y conexiones de usuarios que la misma red social ofrece para todas sus páginas. 


\subsubsection{Soporte de plataforma digital.}

Al no tener conocimientos previos sobre programación web, pero al mismo tiempo, con la intención de que la producción de contenido fuese lo menos complicada, se eligió a Wordpress como plataforma donde se crearía Sync.Pe.

Wordpress es un CMS (content management system), es decir que se trata de una plataforma digital que ofrece la posibilidad de crear blogs y páginas web sin la necesidad de conocer código. De hecho, una de sus principales ventajas es su interfaz, que hace bastante simple configurar y modificar la diagramación de la web, la creación y edición de contenidos, así como el trabajo con el equipo de redacción, ofreciendo la posibilidad de agregar usuarios, editores y administradores.

Wordpress fue, además, de gran ayuda al ser una plataforma gratuita que se podía instalar directamente en el hosting que se había adquirido para Sync.Pe, que contaba con total soporte para este CMS.

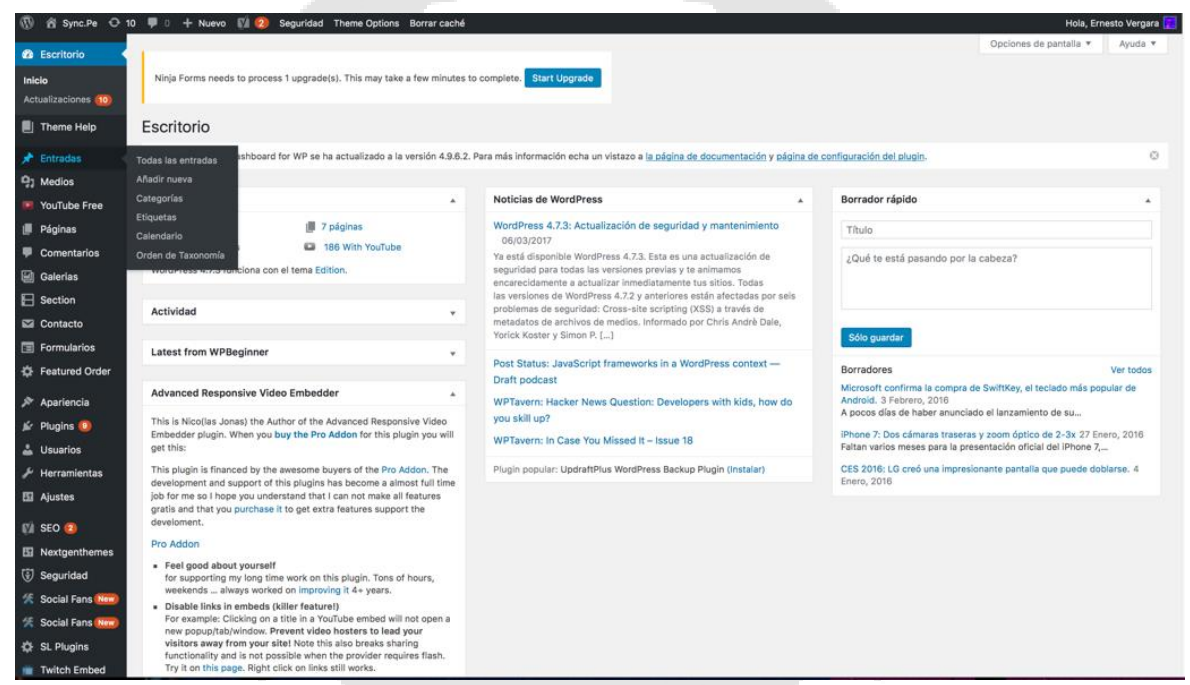

Imagen 3. Interfaz de Wordpress.

Otra gran ventaja de esta plataforma fue la posibilidad de instalar templates o plantillas, y al ser un sistema de código abierto muy popular, existen miles disponibles en Internet tanto de forma gratuita como de pago. De esta forma Sync.Pe pudo tener un diseño profesional y visualmente atractivo con apenas algunas modificaciones en la plantilla adquirida.

Desde Wordpress también es posible anexar contenidos provenientes de redes sociales, así como integrar cuentas propias a la web. Está disponible también la moderación de comentarios y participación del público en la página y en sus contenidos. 
Por último, Wordpress es compatible con una gran cantidad de plug-ins (aplicaciones) que una vez instalados aumentaban las capacidades del site, la producción de contenidos y el seguimiento del desempeño de la web en cuanto a visitas únicas y SEO de los contenidos.

\subsubsection{Arquitectura de información.}

Se decidió ordenar la navegación de la web a partir de los contenidos que esta ofrecía, además de información adicional sobre los creadores del site y formularios de contacto. Es así que el menú principal del site se basó en cuatro bloques contenedores:

- Blog: Noticias y rumores.

- Artículos: Opinión, reportajes, entrevistas, hands-on y coberturas de eventos.

- Análisis de productos.

- Sobre Sync.Pe: "El site” y "quiero escribir en Sync.Pe".

Si bien el menú principal siempre es importante, y para muchos usuarios una buena construcción de este es básica para tener una buena experiencia de navegación, el esfuerzo en cuanto al diseño de la web de Sync.Pe se enfocó en el resto del landing page.
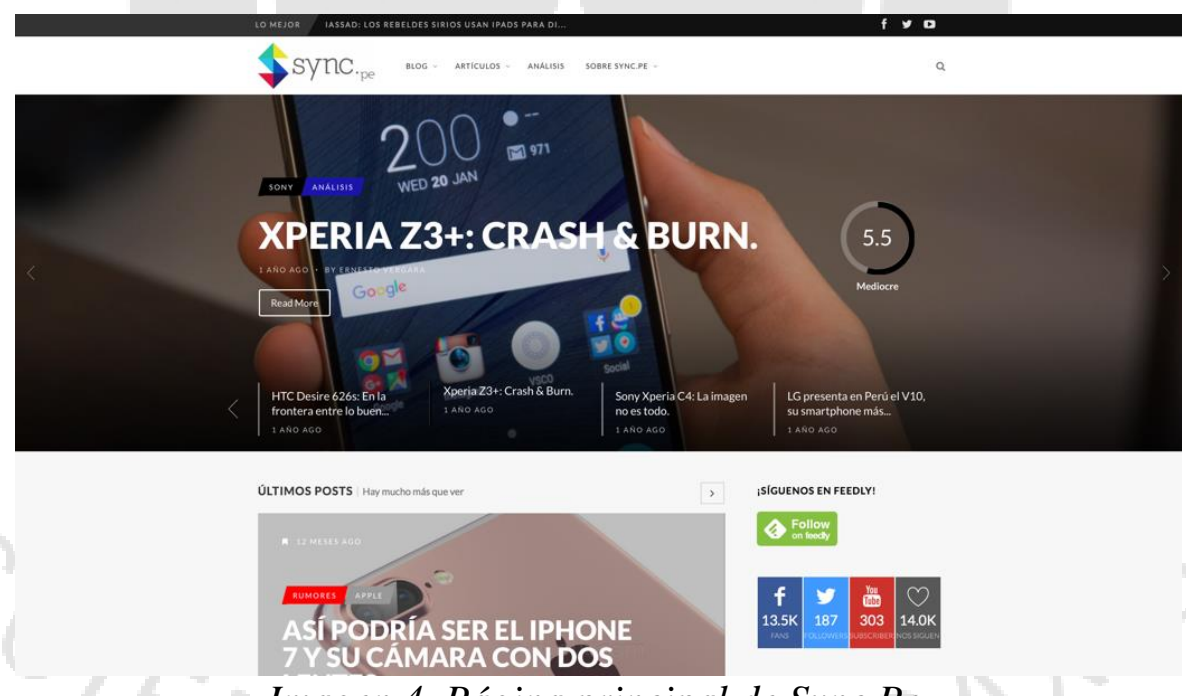

Imagen 4. Página principal de Sync.Pe.

Se crearon, aparte del landing page, dos páginas adicionales con información de Sync.Pe y una construida con el propósito de captar nuevos redactores. Ambas páginas tenían un diseño distinto al resto.

La página llamada "El Site” ofrecería información sobre los inicios de Sync.Pe, sus fundadores, datos de contacto, redes sociales y cuentas adicionales. La sección llamada "quiero 
escribir en Sync.Pe" fue producida con el fin de captar a nuevos redactores. En ella se encontraba una introducción sobre las personas que se necesitaban y datos de contacto para este propósito.

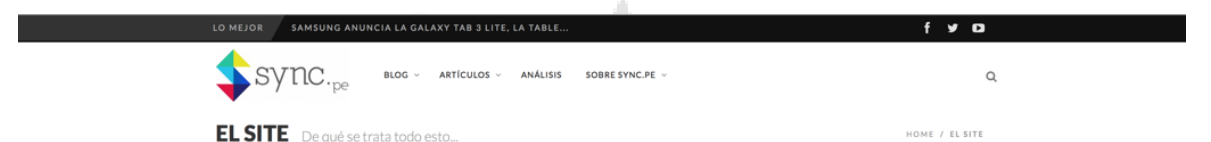

ELSITE

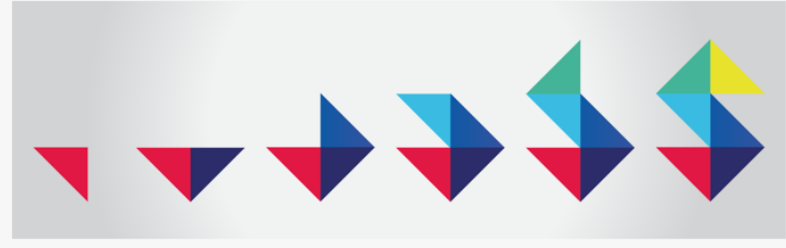

Si has llegado hasta acá...

...es que te interesa saber un poco más de nosotros.

; Graclas por eso

Y como sabemos que a nadie le gusta perder el tiempoe en Interent tvamos, hay

Imagen 5. Página "El Site" en forma de About Page de Sync.Pe.

\subsubsection{Identidad gráfica: diseño de contenidos y página web.}

Luego de tener el nombre elegido y el dominio reservado, un paso muy importante para el proyecto fue la producción del logo que identificara al site. Esto no solo se dio incluso antes de haber elegido una plataforma donde se producirían los contenidos, o hasta dónde se alojaría la información de la web en Internet, sino que fue la creación logo lo que definió varios aspectos de la web, tal como sus objetivos y el resto de la identidad gráfica de Sync.Pe.

Lo cierto es que iniciar el proceso de creación del logo, incluso antes de definir otros aspectos importantes para la base del site, fue al final una ventaja que se supo aprovechar. Al probar las distintas opciones para el isotipo, los colores que este tendría, así como la tipografía que lo complementaría, se tuvo incluso más claro qué tipo de página web de tecnología sería Sync.Pe.

Si los cimientos de Sync.Pe debían ser los contenidos de calidad, entonces se necesitaba un logo que reflejara aquello. Que dejara en claro que se trataba de una web con publicaciones simples, fáciles de entender pero sin descuidar el nivel gráfico e interactivo del site. Es por eso que se prefirieron lineas simples y planas, sin muchas texturas, y por supuesto, sin elementos que fueran referencia a dispositivos de tecnología, algo de lo que muchas webs 
competidoras abusaban. La industria del software ya probaba este estilo en las aplicaciones y sistemas operativos, así que la preferencia por esta corriente de diseño fue bastante lógica.

Se tomó la letra "S" como idea para crear el isotipo, el concepto fue construirla a partir de píxeles (cuadrados), típicos en el lenguaje visual sobre la tecnología, lo que luego se tradujo a elegir triángulos para construir la figura.

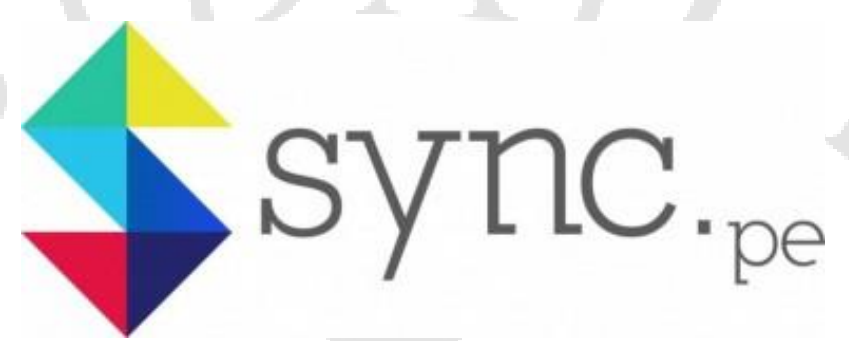

Imagen 6. Logo de Sync.Pe.

Se eligieron 6 colores principales para cada uno de estos triángulos, los cuales funcionarían luego como la paleta de colores de la web. Cada uno de estos colores representaría un tipo de publicación dentro del site:

- Notas informativas y rumores: Azul eléctrico y rojo.

- Artículos: Amarillo y verde.

- Sobre Sync.Pe: Celeste

- Reseñas: Azul oscuro.

Esta combinación de colores no fue elegida al azar, sino que fue determinada usando la herramienta web "Küler" de Adobe, que ayuda a generar combinaciones de colores que se complementen de la mejor forma.

El trabajo con la tipografía, que completaría el logo de Sync.Pe también tomó mucho trabajo en definir. Si bien se necesitaba que la fuente a elegir fuese más funcional que decorativa, es decir, que sea legible por sobre todas las cosas, de todos modos se requería que destaque. Esta fuente era sencilla de reconocer, de leer, y sobre todo, creaba contraste al lado del isotipo de la "S". Tanto así que el isotipo nunca reemplazó la primera letra del nombre de la web, sino que fueron dos productos de diseño que combinados funcionaban tan bien como por separado. El isotipo se integró a los videos en forma de marca de agua, puesto en la esquina superior derecha, además de existir en stickers, por si se quería producir mechandising oficial 
del site. La tipografía, sin ningún isotipo que la acompañe, fue usada como marca de agua en las fotos producidas por la redacción de la web. Ambos elementos combinados, que formaban el logo oficial de Sync.Pe, aparecía tanto en la web, en la firma de los mails, al final de los videos y en cualquier otro tipo de comunicación oficial del site.

El ".pe” dentro del nombre, que tenía que ser pronunciado también, fue reducido en escala y en posición, ubicándose debajo a la derecha con el fin de generar contraste, pero al mismo tiempo equilibrio dentro de los elementos del logo.

El resto de la identidad gráfica siguió lo propuesto por el logo. Se adquirió "Edition" como template para Wordpress, y a partir de este diseño predefinido se construyó el aspecto visual de Sync.Pe. La plantilla fue elegida porque ofrecía muchas ventajas. Como una portada amplia donde las fotos y los titulares eran protagonistas entre los contenidos. Además, el landing page estaba dividido por temas de contenidos, y quedaba un espacio especial para promocionar dentro de ella las reseñas que se producían en la web.

De esta forma, en la parte superior de Sync.Pe se dispuso un ticker rotativo que comunicara las publicaciones más visitadas de la web, debajo de éste se encontraba el logo, el nombre del site y la barra de menú basada en cuatro botones que funcionaban como contenedores. A la derecha se ubicaba el botón de buscar, donde se podía encontrar cualquier tipo de publicación disponible en la página.

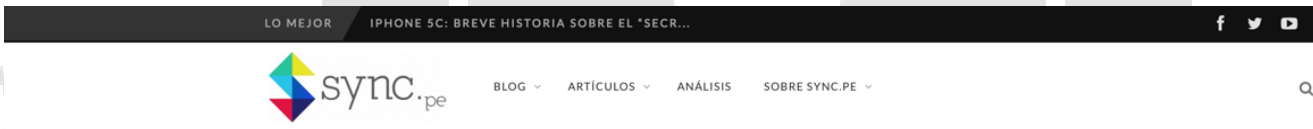

\section{Imagen 7. Menú principal de Sync.Pe.}

Debajo del menú un slider principal le daría la bienvenida el lector, rotando los contenidos a destacar por parte de la redacción de Sync.Pe. La plantilla elegida, Edition, ofrecía la posibilidad de destacar las publicaciones que se necesitaran dentro de este slider. Por lo general se incorporaban a él las noticias más importantes de la semana, las últimas reseñas, hands-on y artículos de interés. Estos contenidos variaban con el tiempo, pero se decidió que solo podrían aparecer ocho de ellos, para que así el usuario siempre encontrara algo nuevo que ver en esta zona. 


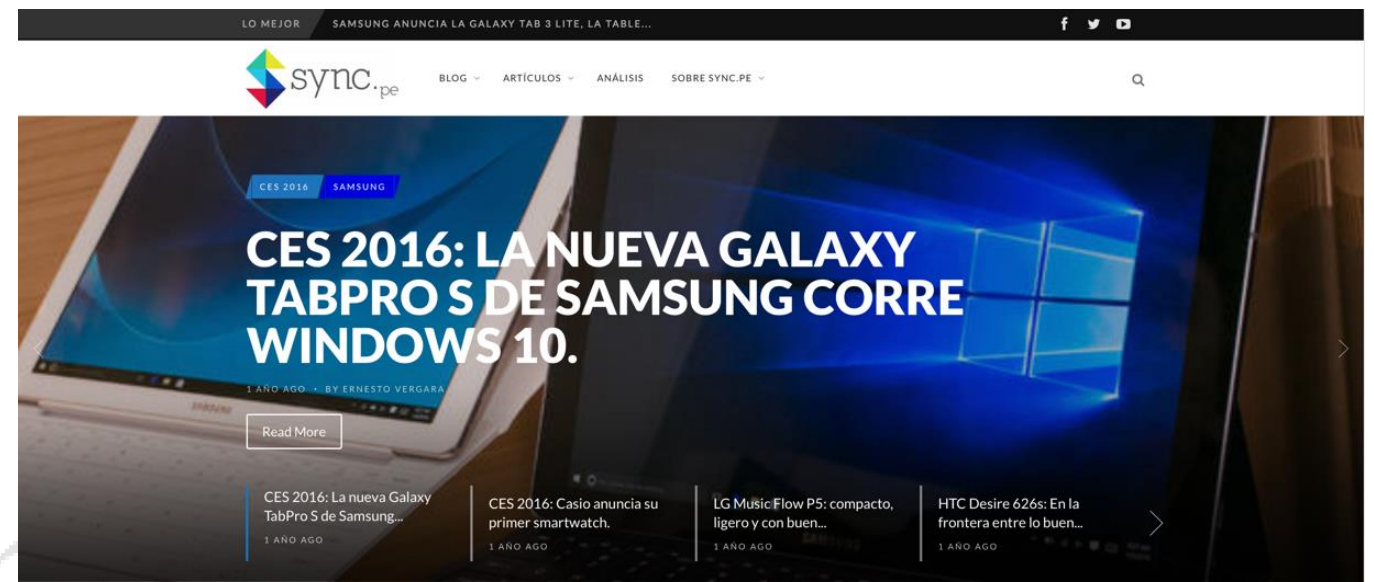

Imagen 8. Slider de Sync.Pe con las publicaciones más importantes.

En la parte inferior al slider principal se encontraba la sección de "últimos posts", que ordenaba en una cuadrícula las publicaciones en orden de cuándo aparecieron en el blog, en lugar de estar compuestas bajo categorías. Se le dio espacio para cinco piezas de contenidos, de esta forma el lector tendría a la vista lo más reciente del día en la web.

Al lado de esta cuadricula se ubicaron los widgets, pequeñas aplicaciones con funciones específicas para mejorar la navegación en el blog, además de añadir características exclusivas. De esta forma se ubicó un botón para que el público pudiera seguir los contenidos del site desde Feedly, una sección con las redes sociales y las cuentas adicionales de la publicación, un segmento que ordenaba los posts más vistos de la web por semana, mes y desde el inicio de Sync.Pe, y finalmente, una recuadro que conectaba al site con su página oficial en Facebook.

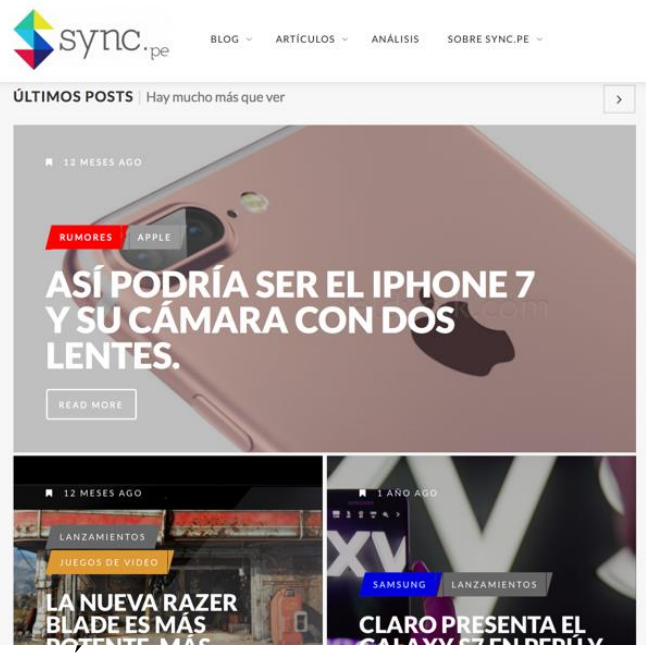

¡SIGUENOS EN FEEDLY!
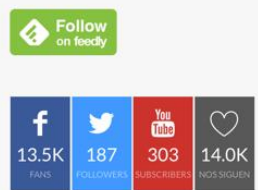

LOMAS VISTO

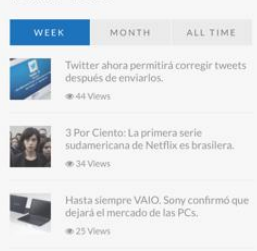

Imagen 9. Sección "Ultimos Posts" y barra lateral de widgets con información adicional.

Debajo, tanto del grid de "últimos contenidos", así como la barra lateral de widgets, se encontraba un banner rectangular que iba de extremo a extremo de la pantalla. Esa sección 
fue definida para promocionar las reseñas que se hacían en Sync.Pe. Contenidos que eran considerados la especialidad de la web.

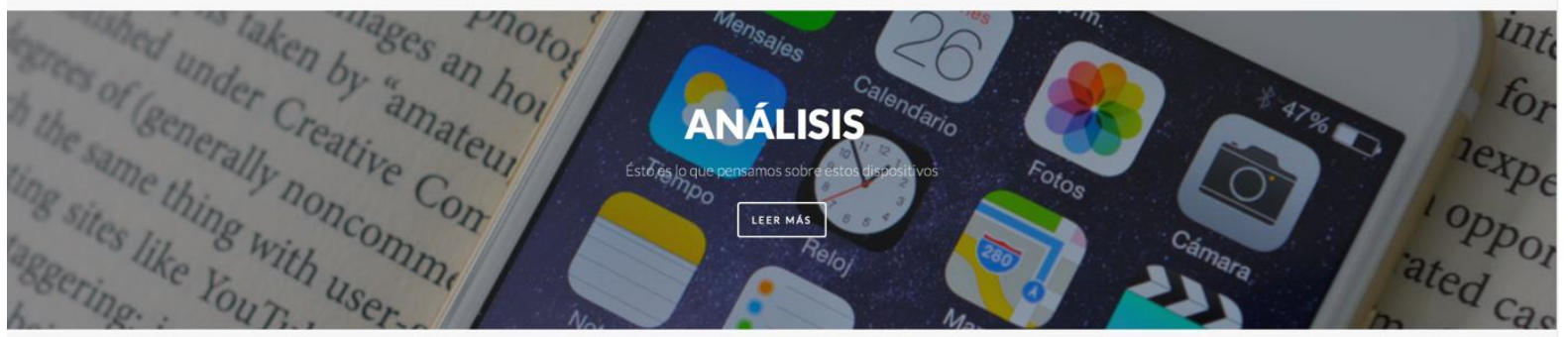

Imagen 10. Banner exclusivo para promocionar las reseñas de productos.

Las ultimas dos secciones inferiores les correspondían a los artículos, que se ordenaban en un slider de tres contenidos por vez, pero que a partir de botones laterales, podrían mostrarse otras publicaciones similares y de interés para el usuario. En este segmento se ordenaban tanto los artículos de opinión, los lanzamientos y coberturas de eventos locales e internaciones, así como los rumores sobre nuevos dispositivos que aun no salían al mercado. Al fondo del landing page se encontraba el footer de la página web, que contaba con tres columnas con un widget en cada una de ellas. A la izquierda uno de texto ofrecía una breve introducción de Sync.Pe, al centro se ordenaban las redes sociales y la cuenta de Youtube del blog, y a la derecha aparecían nuevamente los contenidos más vistos de la semana, el mes y desde el inicio de la publicación.
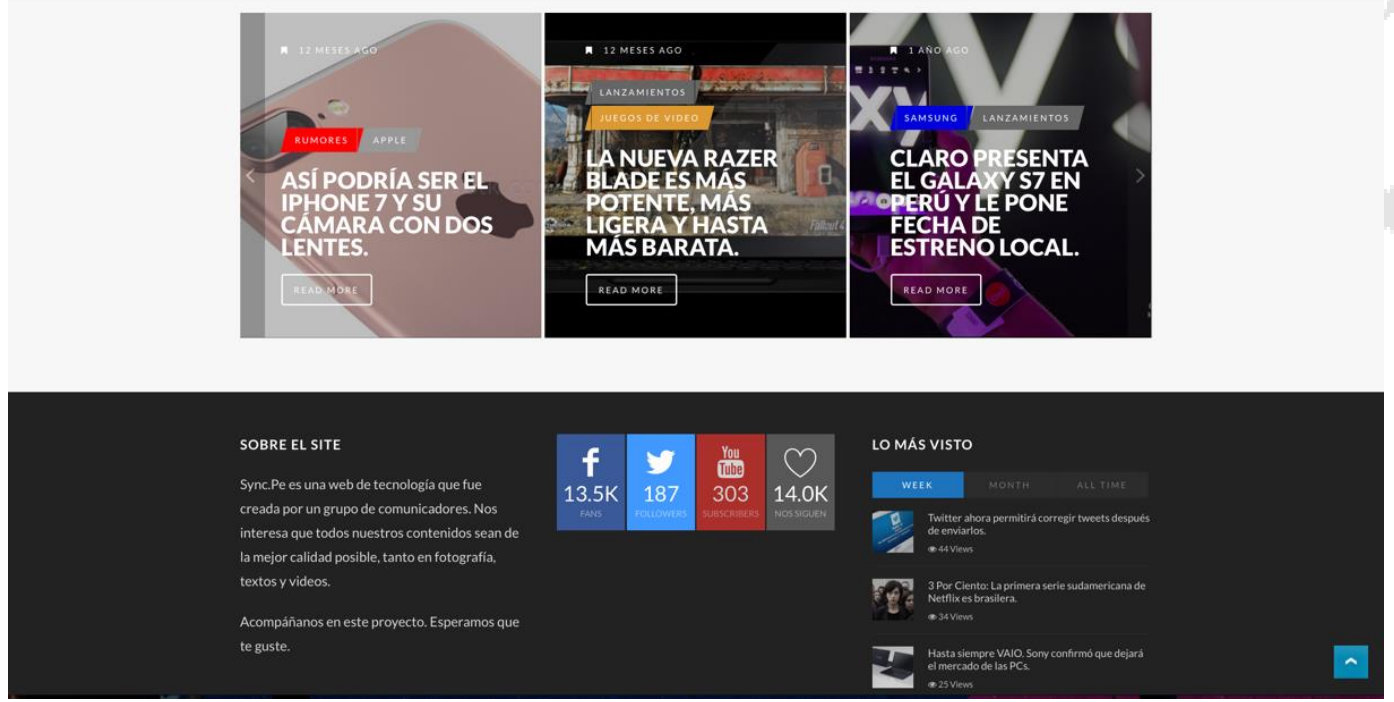

Imagen 11. Slider exclusivo de "Artículos" y el footer con información adicional. 
De todos modos, a pesar de contar con una plantilla predefinida, se produjeron cambios en ella y se agregaron nuevas funciones que no venían incluidas en el template. Uno de estos cambios fue la inclusión de un aplicación que permitiera crear columnas dentro de las páginas de contenido. De esta forma los textos podrían ser acompañados con fotos a los lados con un mayor control por parte del autor.
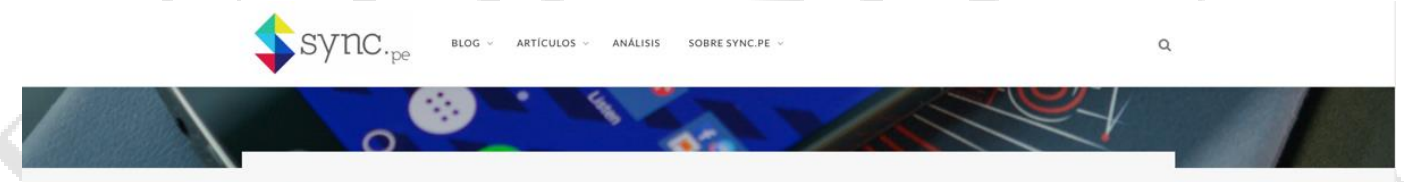

1. EL LG G4 no es una alternativa más al Galaxy $\mathrm{S6}$, sino una de las apuestas más seguras a

mejor teléfono Android de 2015

- No se necesita ser ningún genio para hacer reseñas de smartphones.

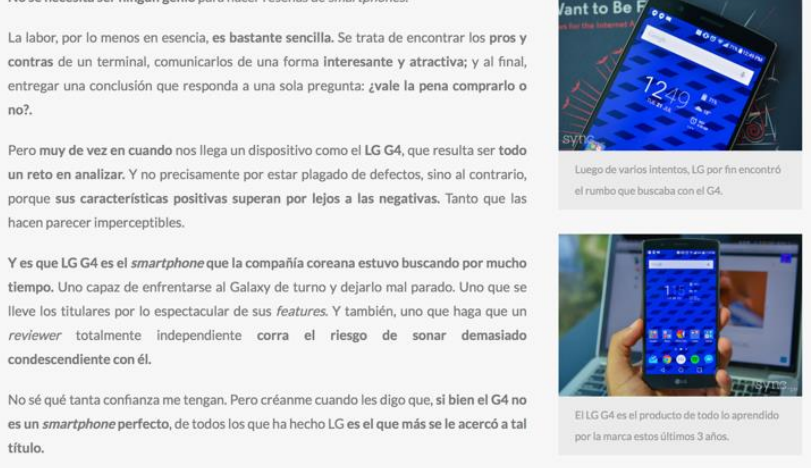

Imagen 12. La modificación por columnas permitió aprovechar la extensión de la pantalla.

Por último, tanto Wordpress como la plantilla Edition, permitían que la página web puede ser visualizada tanto en la pantalla de una PC de escritorio, laptop, tablet y smartphone. Este tipo de programación llamada responsive design logró que los contenidos de la publicación se ordenaran dependiendo de la pantalla donde eran vistos, y fue fundamental ya que, según la investigación que se hizo sobre el público objetivo, se encontró que buena parte de ellos acudían a ésta a partir de dispositivos móviles, incluso más que estacionarios como se pudo pensar en un principio. 

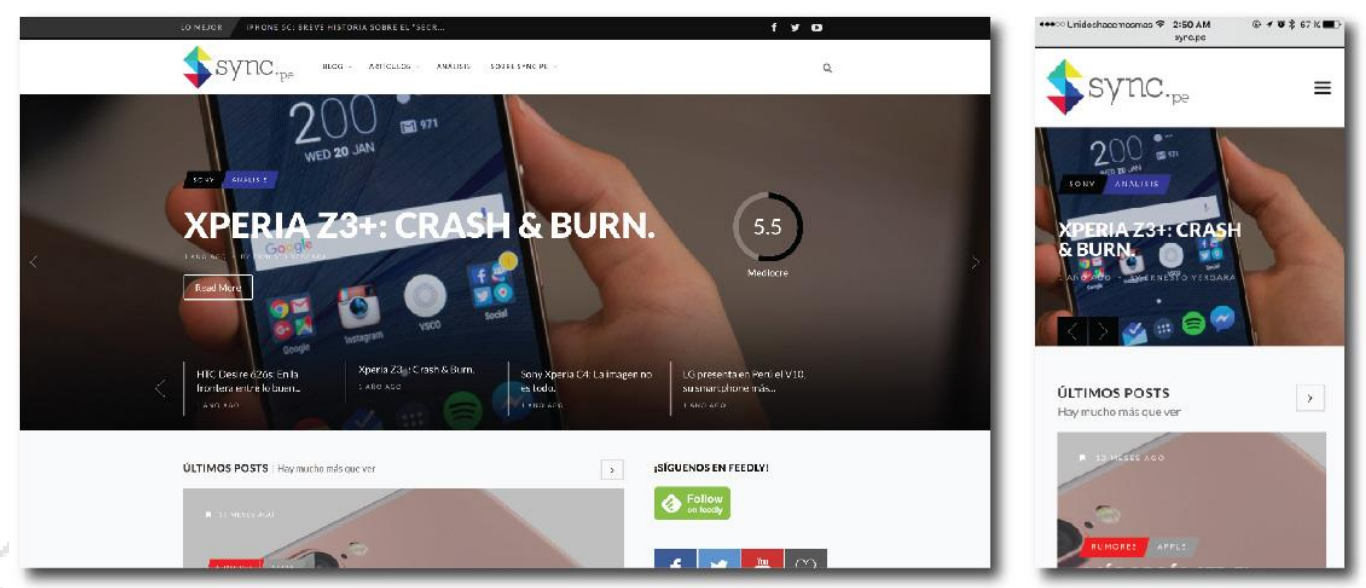

Imagen 13. Diseño responsive. Derecha, Sync.Pe en una laptop. Izquierda en un iPhone.

\subsubsection{Tono de comunicación y estilo.}

En Sync.Pe se estableció un tono de comunicación y un estilo que incorporara los valores de la página: la independencia y el enfoque en el público objetivo. Mientras que el primero abordaba la independencia de la publicación, el segundo se enfocó en las necesidades del usuario. La definición de ambos elementos requirió un estudio interno del site cotejado con la información que se tenía ya del público objetivo.

Para las publicaciones del site se buscó un tono de comunicación directo, inteligente, abierto a conversar con el público, respetuoso de las marcas, pero distanciado de ellas. El concepto detrás de la voz de Sync.Pe fue el de un amigo que sabe de tecnología, es apasionado por ella, le gusta compartir sus conocimientos, pero al mismo tiempo, no pierde el sentido crítico sobre las compañías que producen los dispositivos que tanto le interesa. Aunque en algún momento se experimentó con el sarcasmo y con el humor, poco de aquello quedó y se le dio prioridad a la crítica sincera y al enfoque en lo que al público le convenía, sobre todo cuando se trataba de contenidos como reseñas de productos. 
Y no es su diseño repetido del modelo anterior. Tampoco el procesador Snapdragon 810, que en tiempo record convierte el smartphone en una estufa. Mucho menos la cámara de 20.7M, que no entrega resultados tan impresionantes como ese número prometería. $Y$ aunque podría considerarse, no me refiero al mediocre rendimiento del teléfono que pocas veces aparece en un flagship.

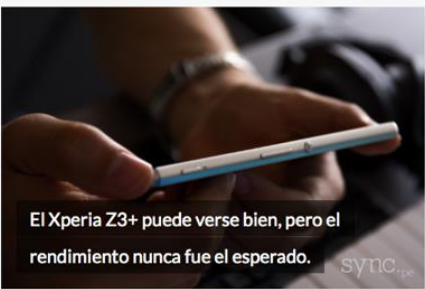

El gran problema con el Xperia Z3+ es su falta de inspiración. Esa sensación de que Sony lo lanzó para cerrar números, para completar la cuota de lanzamientos. Incluso escribir sobre él se me complica, y es que esperé todo menos lo poco que me entregó el sucesor del extraordinario Xperia Z3.

Ésta no es la historia que me hubiera gustado escribir.

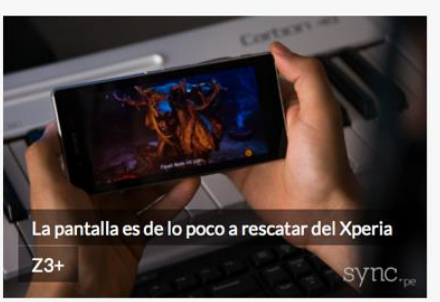

Imagen 14. Ejemplo del estilo y tono de comunicación en las reseñas de Sync.Pe.

El estilo varió con el tiempo y también sufrió algunas alteraciones, pero se fijaron ciertas reglas que debían respetarse por cada uno de los redactores de la web. Reglas que no solo abarcaron la elaboración del texto, sino también de otros tipos de contenido, como los gráficos, los videos y el audio.

\subsubsection{Estrategias de contenido.}

Se estableció producir cuatro publicaciones todos los días de lunes a sábado. Los tipos de contenidos elegidos para producir fueron:

- Notas informativas: noticias importantes en el mundo de la tecnología.

- Rumores: notas informativas sobre datos aun no confirmados de productos que saldrían al mercado próximamente.

- Artículos de opinión e interés: tips, comparaciones, editoriales.

- Hands-On: Primer vistazo a productos que acaban de ser lanzados o han llegado a nuestras manos para ser reseñados.

- Reseñas de productos: hardware y software.

- Coberturas de eventos.

- Especiales: Reportajes, entrevistas, etc. 


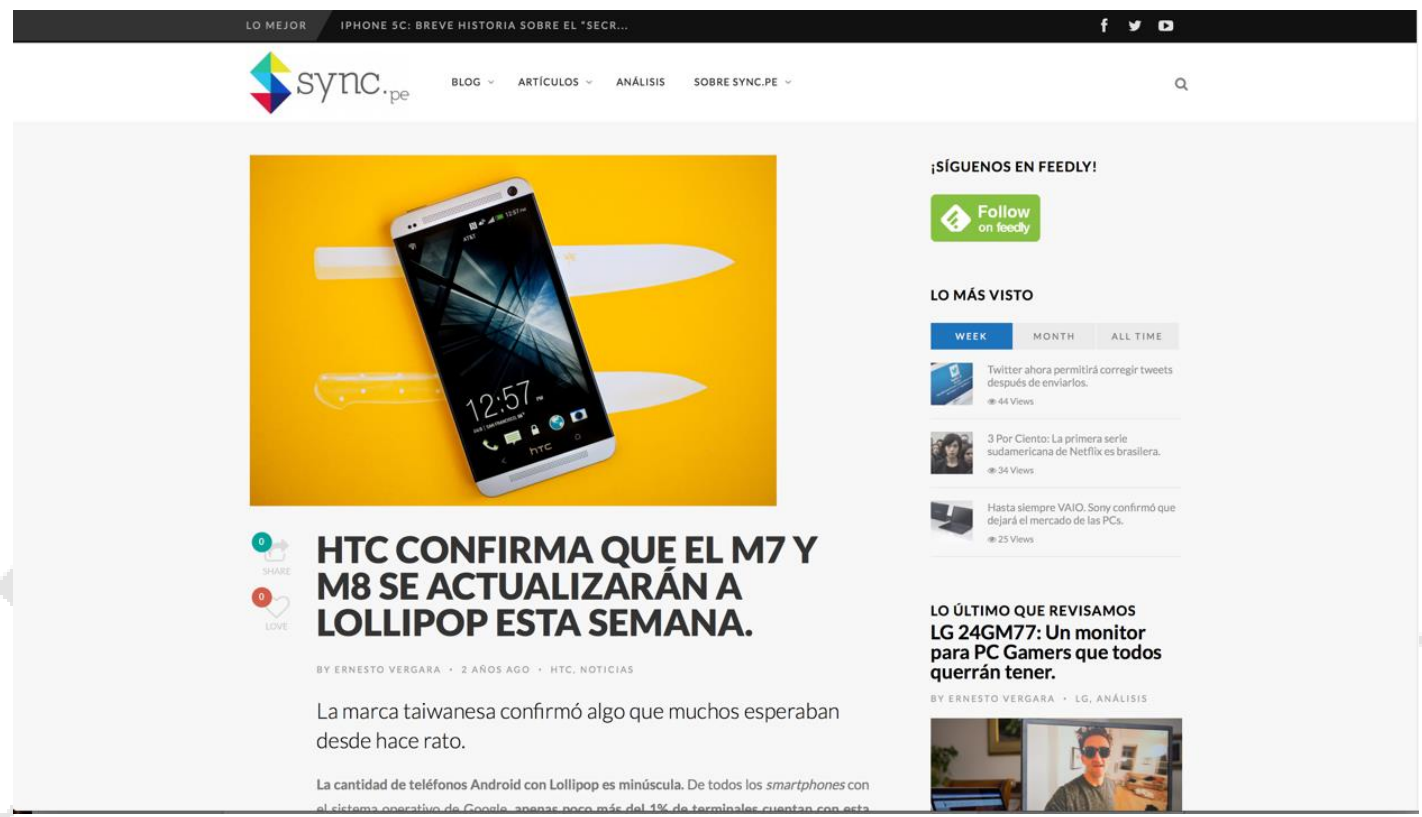

Imagen 15. Nota informativa en Sync.Pe.

De hecho, y en base a lo que propone Brogan y Smith (2012), cada uno de estos tipos de contenido siguieron la fórmula mencionada en el libro "The Impact Equation", donde elementos como contraste, alcance, exposición, articulación, confianza y eco, ayudarían a Sync.Pe a producir publicaciones relevantes.
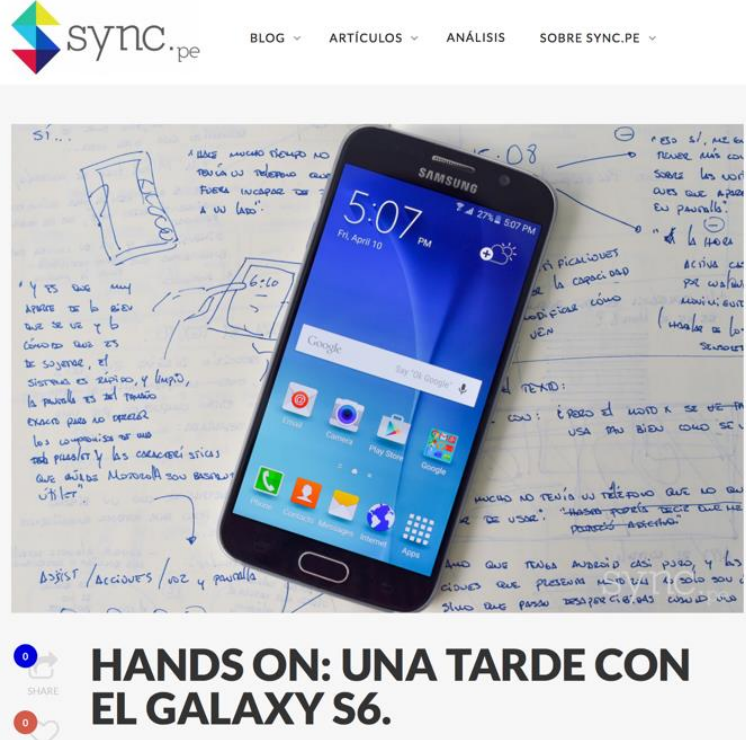

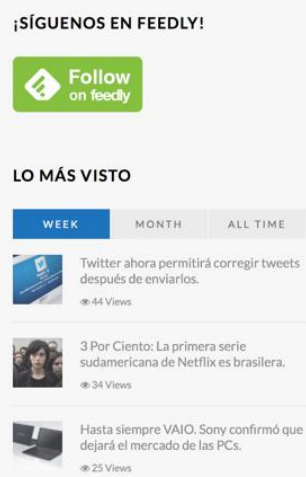

LO ÚLTIMO QUE REVISAMOS

LG 24GM77: Un monitor

para PC Gamers que todos querrán tener.

Imagen 16. Artículo hands-on en Sync.Pe.

De esta forma, el contraste se aseguraría a partir de la calidad de estos, tanto de los textos como de las fotos y videos, lo que lograría que el site tuviera un valor que lo destaque 
entre la competencia. Por eso mismo, se definió que las reseñas de productos fueran las publicaciones que más cuidado deberían tener.

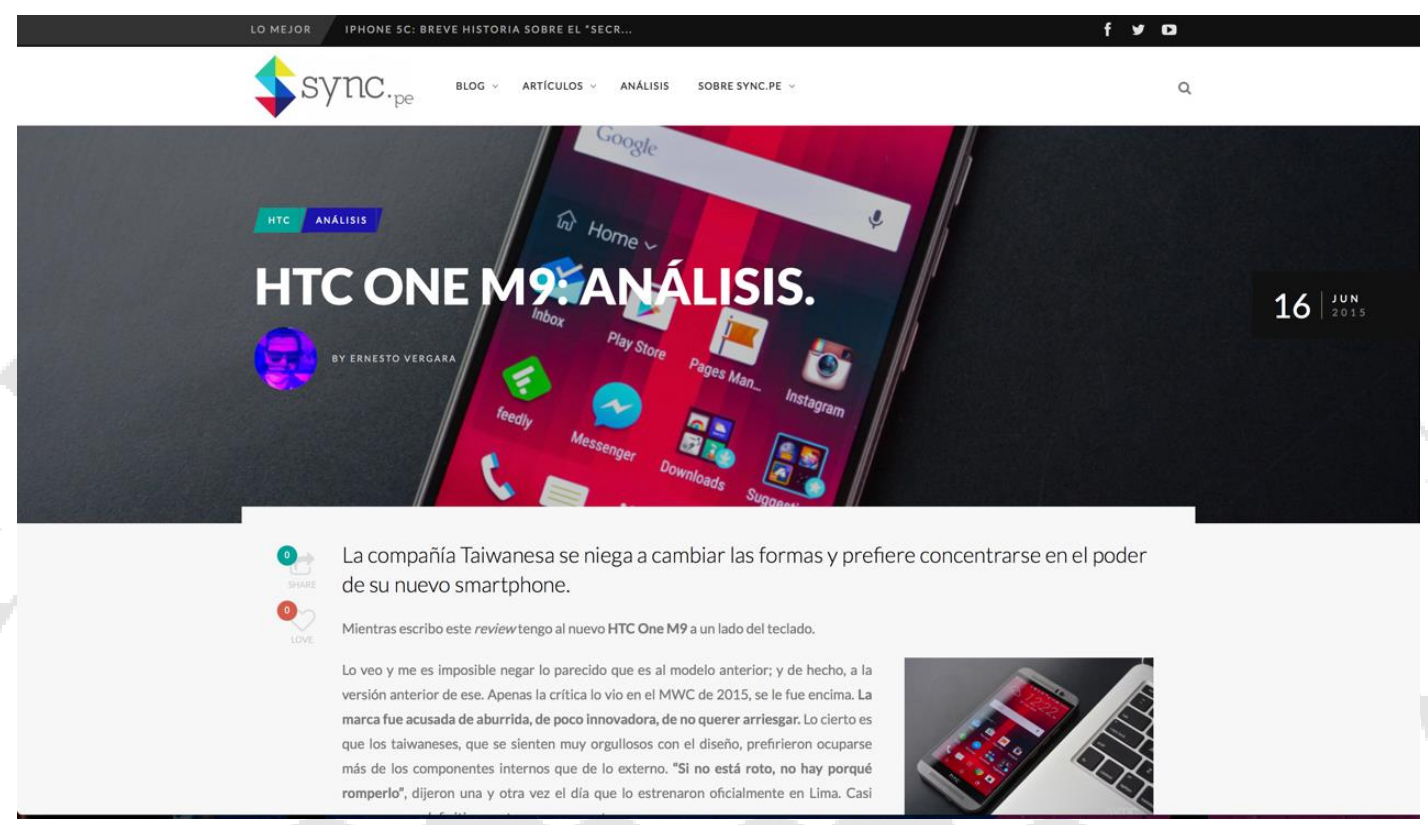

Imagen 17. Reseña de producto en Sync.Pe.

En cuanto al alcance, se decidió que en el mix de contenidos existieran tanto publicaciones genéricas (notas informativas, rumores, etc.), como piezas exclusivas de la web. Así, el usuario de Sync.Pe siempre sería capaz de encontrar contenidos que le fueran de su interés.

Sobre la exposición, se decidió que los contenidos aparecerían en distintas plataformas digitales: primero en el blog, luego en Facebook, Twitter, y si así fuera el caso, en videos o fotos en Instagram. Por lo menos desde la web y en las redes sociales, el usuario del site sería expuesto a cuatro piezas de contenido diarias.

Para lograr generar articulación en los contenidos, estos se producirían a partir de ciertos estándares de producción de texto, foto, video y audio; los cuales asegurarían que todas las publicaciones, estén en el formato que estén, serían simples de entender así como útiles para el lector.

La confianza, como se estableció dentro de los valores de Sync.Pe fue un elemento fundamental dentro de la estrategia de contenidos. Cada una de las publicaciones debía demostrar un punto de vista en particular: el del autor. Las reseñas, entonces, serían muy importantes para establecer la credibilidad del site, al ser contenidos enfocados únicamente en lo que le conviene al lector. 
El eco, la posibilidad de crear una comunidad de fanáticos del blog, se daría una vez cumplidos los elementos anteriores de la fórmula de Brogan y Smith (2012). Para un nuevo site es fundamental conseguir con el paso del tiempo a usuarios fieles, que siempre retornen a la web, y que además, compartan publicaciones que ayuden a acercar a otros visitantes al site. Tener contenidos distintos al resto de la competencia, variados entre sí, fáciles de ubicar en cualquier plataforma digital, así como sencillos de entender y que demuestren objetividad, ayudarían a que Sync.Pe se establezca como uno de los mejores blogs de tecnología para sus potenciales seguidores.

\subsubsection{La producción y definición de tipos de contenido.}

Antes de la creación de Sync.Pe como proyecto, así como durante el tiempo que el site funcionó en Internet, se establecieron ciertas pautas de creación de contenido para cada tipo de pieza a publicar en el blog.

Todos los contenidos de Sync.Pe estuvieron basados en combinaciones de texto, fotografía, audio y video, siendo cada uno de estos protagonista de cada formato de publicación. En este sentido los textos del blog eran protagonistas cuando se trataba de producir una nota informativa, un artículo de interés o un artículo de opinión. Las fotografías eran protagonistas, junto con los videos, en contenidos como entrevistas, hands-on, coberturas de eventos y por supuesto las reseñas de productos, finalmente la producción de contenidos basados en audio aparecieron mediante la participación del site con Coca Cola FM, que se asoció al blog dándole un espacio dentro de su programación, en una primera etapa como cápsulas de contenido entre los shows de la radio por Internet, para luego pasar a un programa semanal con transmisión en vivo.

De todos modos, las reglas de creación de contenido estuvieron basadas en parte de lo que Ann Handley y C.C Chapman (2012) afirman en The Content Rules. Por ejemplo, sobre la característica de "verdad", se estableció que cada una de estas publicaciones tenía que ser sincera, basada en la verdad y no aumentada ni modificada para conseguir clicks y visitas fáciles que, finalmente, no crearían la comunidad de lectores deseada. Es por eso que se tuvo mucho cuidado, no solo en la construcción del texto para notas informativas, artículos, reseñas, etc. sino que se estableció producir titulares que presenten las historias sin engañar al público sobre la importancia real de estas. El objetivo fue evitar que Sync.Pe sea visto como un site donde el clickbait, la acción de producir titulares falsos o exagerados para captar la atención 
inmediata del público, jamás sea usada en la estrategia de contenidos así como en la construcción de estos.

Si bien las reglas de "propósito" y "humano" ya se tenían en cuenta a partir de lo propuesto por Brogan y Smith (2012), donde los contenidos deben tener una razón de ser (educar, informar, guiar, entretener), además de que el lenguaje utilizado en ellos sea familiar para el público objetivo, se tomó en cuenta la característica "pasional” que Handley y Chapman (2012) mencionan en The Content Rules. Se trata que los contenidos de Sync.Pe estén basados en un tono de comunicación que deje claro tanto el punto de vista del site, así como sus valores, además del fanatismo que tienen los autores de este por la tecnología. Por último se rescatan las características de "original” y "sorpresa”. La primera ayudó a definir cómo se dividirían los contenidos propios de Sync.Pe junto con genéricos, tal como notas informativas o rumores. Se propuso que el $60 \%$ de publicaciones de Sync.Pe debían ser propias: reseñas, artículos, tips, comparaciones, hands-on, etc. Mientras que el resto del $40 \%$ estaría basado en contenidos comunes entre otros blogs similares, pero que son de interés para el público. La característica de "sorpresa" se enfocó en darle al público piezas con una calidad que mejore continuamente. A pesar de que se establecieron reglas de creación de contenido, se tuvo en cuenta que para entregarle nuevos productos al usuario, y así mantener su atención, invertir en equipos de grabación, edición, así como buscar locaciones interesantes era fundamental para innovar y renovar la calidad del site, y también, alejarse aún más de la competencia.

\subsubsection{Sobre los textos.}

Se definieron reglas específicas que respetaran tanto el tono de comunicación elaborado para Sync.Pe como también el estilo construido para las publicaciones:

- Textos de extensión corta e ideas concisas por párrafos: Se estableció un máximo de dos comas por oración (a menos algunas excepciones que afecten la calidad de la redacción o la claridad del mensaje).

- Las oraciones podían ser cortadas con el fin de generar ritmo y energía en el texto, y de esta forma llamar la atención del lector.

- Era válido comenzar una oración con “y”, “pero”, "porqué”.

- Los párrafos debían tener una extensión de no más de 5 líneas.

- Luego de cada 3 o 4 párrafos se debía agregar una foto y un subtítulo.

- Cada párrafo debería desarrollar una sola idea. 
- El titular debía llamar la atención pero tampoco explicar la historia completa de la publicación.

- Se debía tener en cuenta una bajada para el titular.

- Sombrear en negrita las frases y palabras claves del texto.

\section{Una cámara sin miedo a la oscuridad.}
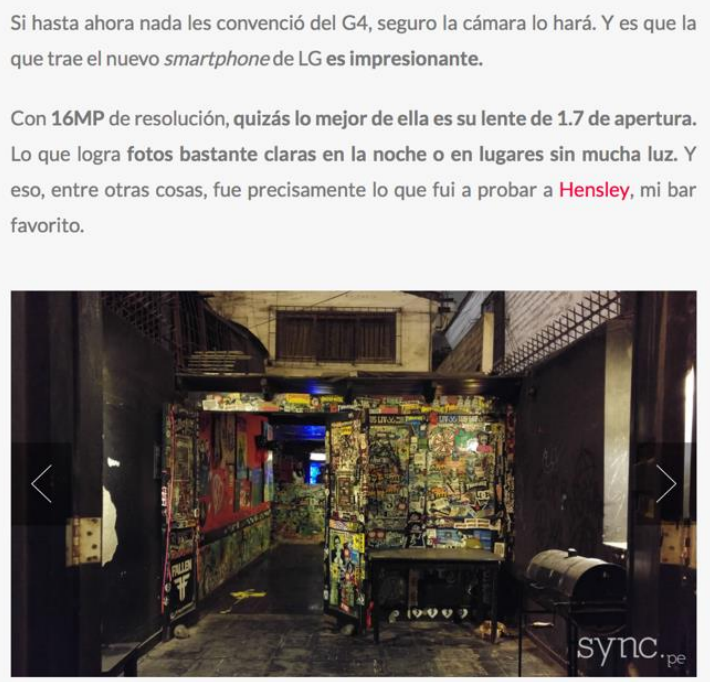

$\bullet \bullet \odot$

Imagen 18. Ejemplo de la creación de textos cortos en la redacción de contenidos.

\subsubsection{Sobre las fotos y videos.}

Si bien el texto era la base de la comunicación de Sync.Pe como blog, los videos y las fotografías producidas exclusivamente para las publicaciones fueron lo que el público más apreció de los contenidos del site. Se elaboraron estas reglas:

- Los videos y fotos creados por Sync.Pe deben ser realizados por lo menos con cámaras DSLR.

- Las cámaras de video deberían estar siempre soportadas por un trípode, un slider u cualquier otro equipo similar.

- Primar el uso de la luz natural frente a la artificial, sobre todo si se trata de una reseña de producto.

- Usar locaciones reales. Preferir lugares en donde transite o asista con regularidad el público objetivo, en especial si se trata de reseñas de productos.

- Tanto las fotos como los videos deben mostrar a una persona probando las funciones de los productos, tanto para los contenidos de hands-on como para las reseñas. 
- De la selección final de clips y de fotografías, el $60 \%$ de debe mostrar a una persona probando el dispositivo y el resto serán tomas con el producto solo.

- Encuadrar tomas y fotografías a partir de la regla de los tercios.

- La selección y edición fotográfica se realizará en Adobe Lightroom.

- La edición de video se realizará en Adobe Premiere Pro CC.

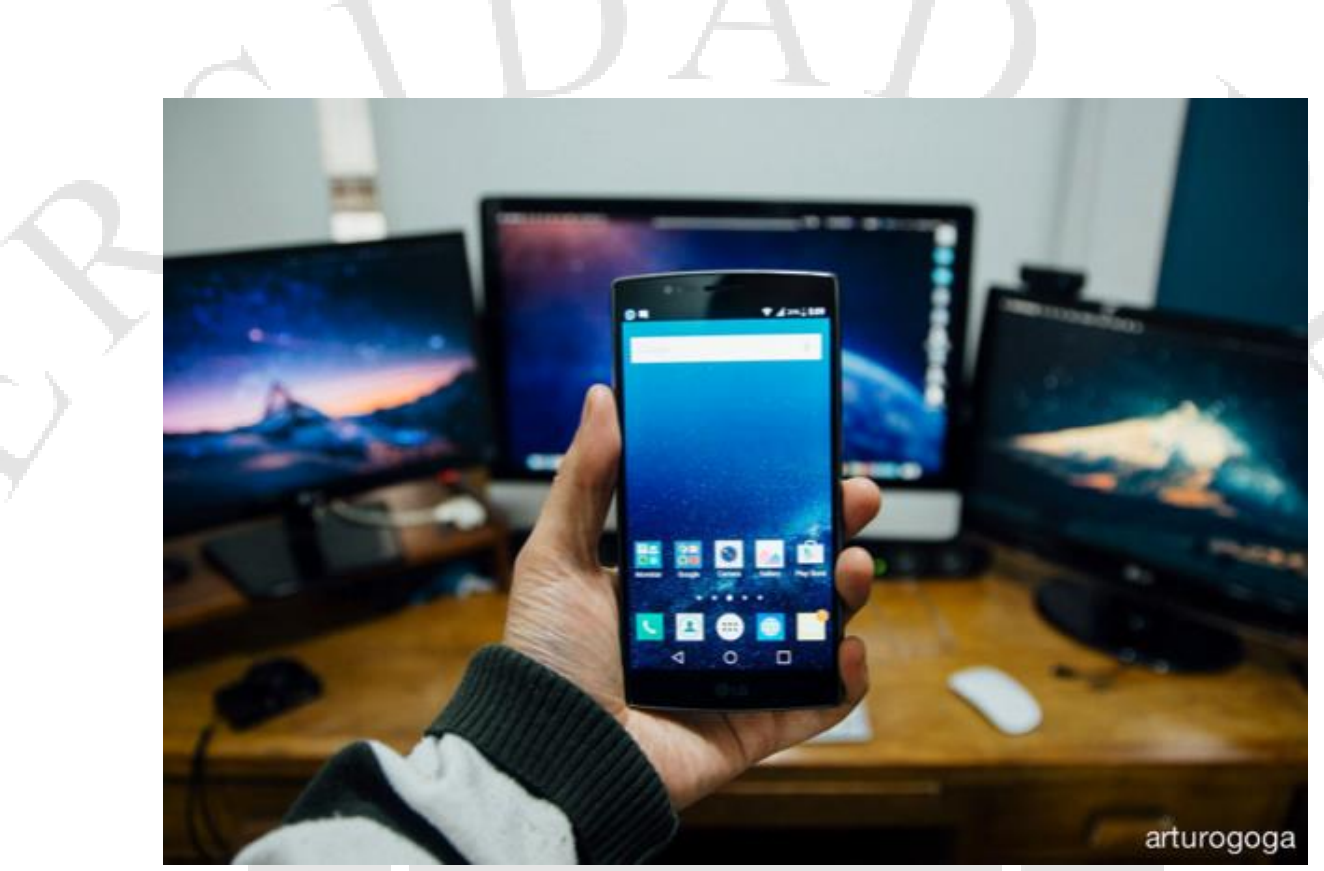

Imagen 19. Foto de la reseña del smartphone LG G4 por Arturogoga.com

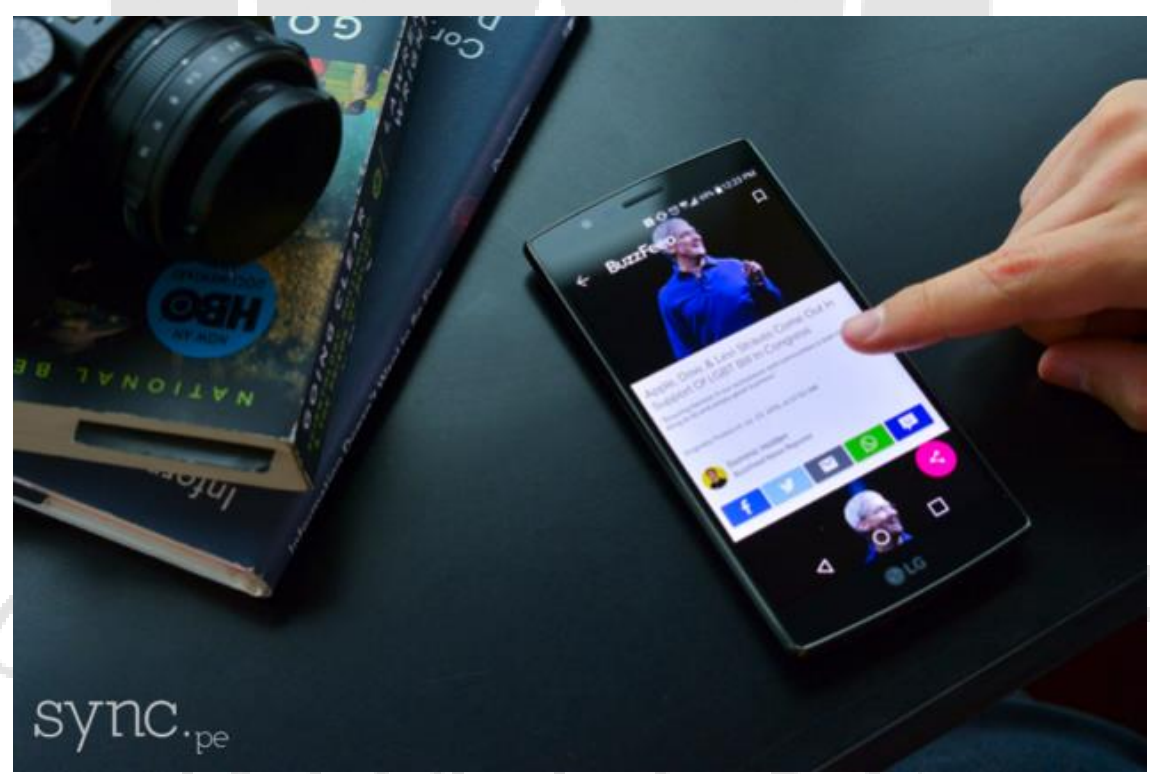

Imagen 20. Foto de la reseña del smartphone LG G4 por Sync.Pe. 


\subsubsection{Sobre el audio.}

Si bien se planificó la creación de podcasts y programas especiales en audio, que se alojarían de manera exclusiva en el blog, así como en las redes sociales y páginas especializadas asociadas a Sync.Pe, estos contenidos no pudieron llegar a producirse. De todos modos, la web tuvo dos tipos de participación en la radio online de Coca Cola: primero como pequeñas cápsulas de contenido de tres minutos cada una (“Gulas”), que aparecerían dentro de la programación de este medio. Luego de dos meses la radio le ofreció a Sync.Pe un programa en vivo de dos horas de duración. La producción de estos contenidos fue responsabilidad del site y se elaboraron reglas para asegurar la calidad de estos. Además se añaden a continuación las normas a seguir al capturar audio para video y locuciones en off:

- En entrevistas, reportajes y locuciones, el audio debe ser registrado a partir de dispositivos de captura externos a la cámara.

- Deben usarse micrófonos correspondientes para cada situación. Estacionarios si se trata de locuciones y pecheros si se trata de entrevistas.

- Para los "Glups" de Coca Cola se elaborará una lista de 10 temas a tratar, que tienen que ver con noticias, rumores, micro reseñas de productos, etc.

- El programa de radio en vivo debe basarse en un guión predefinido con secciones que mezclen las noticias más importantes de la semana, reseñas de productos y contenidos especiales creados en exclusiva para Coca Cola FM ("tres minutos en el futuro", "versus" o reseñas en vivo).

- El programa en vivo debe estar basado en el contraste de las personalidades y preferencias de ambos conductores: Eduardo, más energía y fanático de Android. Ernesto, más calma y fanático de Apple.

\subsubsection{Equipos y software.}

Se utilizaron, para la creación de contenido fotográfico y audiovisual, una serie de dispositivos y de programas para elaborar las publicaciones de Sync.Pe.

Para fotografía y video se usaron dos cámaras. Cómo cámara principal se eligió la Nikon D5200. Si bien no es necesariamente un modelo profesional, combina muchos factores que la hicieron la cámara perfecta para los contenidos del blog. Por un lado, la calidad del sensor APS-C ofrecía fotografías de muy buena definición y color, y sus 24 megapíxeles hacían 
que ampliar las imágenes fuera sencillo y sin perder información vital para el resultado final. Además, la capacidad de video de la cámara era muy superior a sus competidoras.

Se utilizaron dos lentes para esta cámara, un Nikon de 40mm con capacidades de Macro, que resultaba perfecto para producir tomas de detalle de productos y un lente Sigma 18-70 con apertura constante de f/2.8, que era perfecto para utilizarse en lugares con baja iluminación.

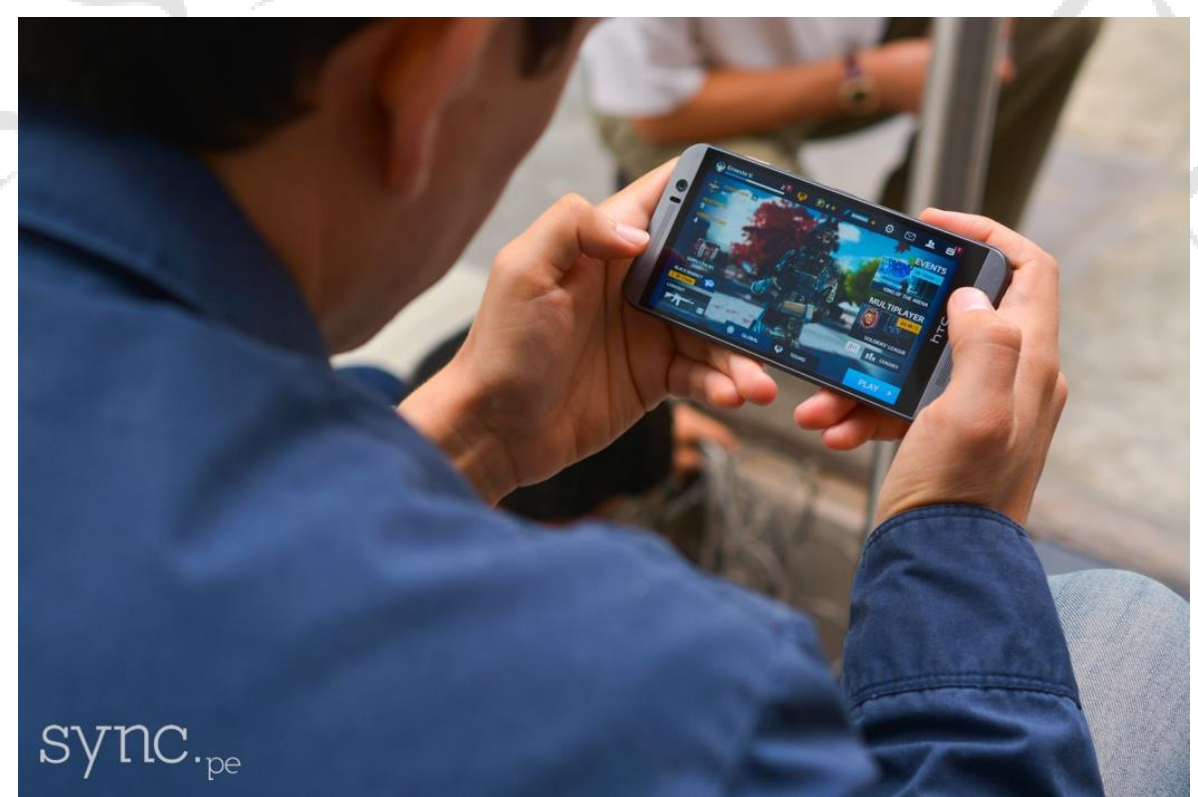

Imagen 21. Foto editada para publicación de la reseña del smartphone HTC M9.

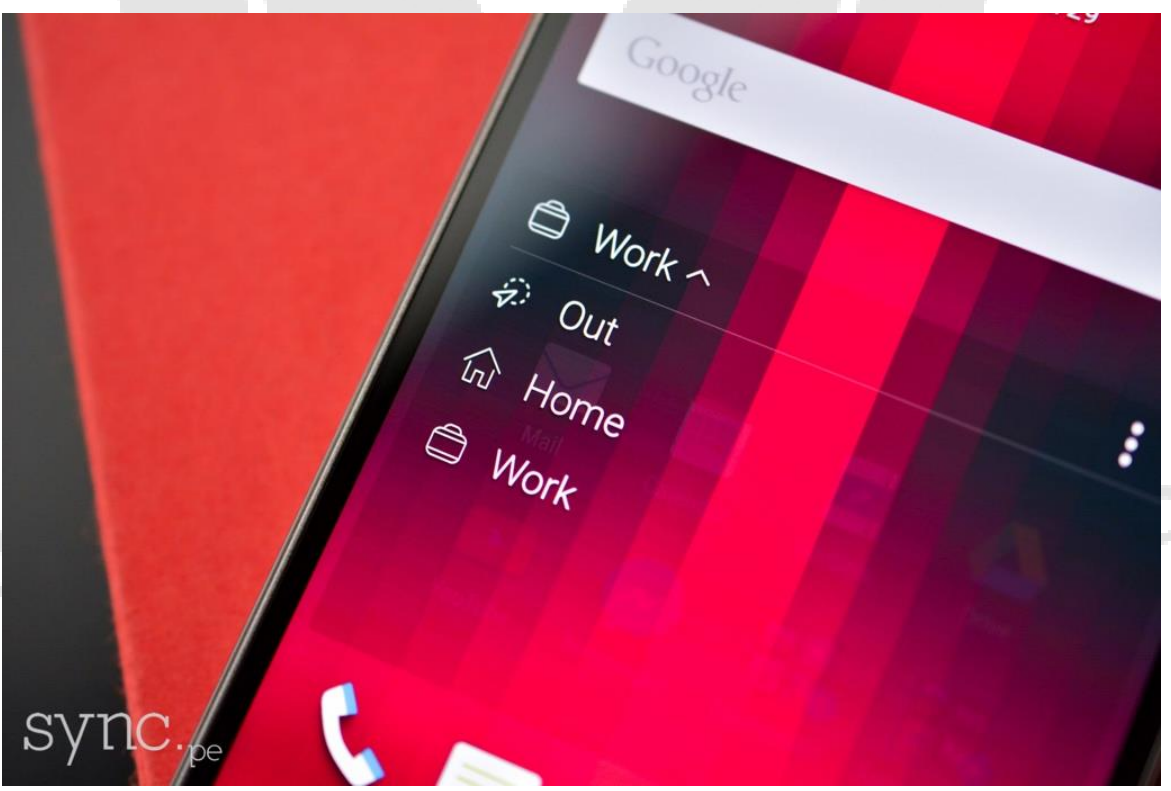

Imagen 22. Foto editada para publicación de la reseña del smartphone HTC M9. 
La segunda cámara, una Panasonic LX100, permitía realizar video en 4K. Esto resultó muy conveniente en edición, ya que era posible recomponer las tomas registradas con esta cámara sin el riesgo de perder calidad, al ser la exportación final en 1080p.

Como soporte se utilizó un trípode Manfrotto 055XPROB, que permitía además de las funciones básicas, la posibilidad de sostener la cámara en posición cenital, lo que facilitaba en gran manera el trabajo de realización de tomas de producto.

En el audio se usaron micrófonos del tipo lavalier de distintas marcas. Estos fueron usados principalmente para las entrevistas. Para el registro de este material se utilizó una grabadora Tascam D-40. Para las locuciones en off se utilizó un micrófono unidireccional Samson.

\subsection{Resultados}

Al cierre de Sync.Pe se percibieron dos tipos de resultados. Los resultados que se dieron gracias a la calidad de contenidos que ofrecía la publicación, algo que benefició tanto al prestigio que logró el site como a sus fundadores; como también los que tenían que ver con la página en sí: visitas, clicks, likes en Facebook, reach en redes sociales, etc.

\subsubsection{Resultados cualitativos.}

Uno de los objetivos de la publicación era llamar la atención de marcas de tecnología, y de esta forma, ser parte del grupo de medios digitales que estas convocaban para sesiones de prensa, y además, préstamos de productos; esto resultaba fundamental para un blog de tecnología que necesitaba de estos para generar contenidos como hands-on y reseñas de productos. Este objetivo fue alcanzado en Enero de 2014, cuando Sony contactó a los creadores del site para incluirlo en su lista de medios digitales, y además, con el fin de crear una reseña de la nueva consola de juegos de video de la marca, el Playstation 4.

Luego de Sony se sumó Linio, que conoció de Sync.Pe gracias al periodista Jesus Veliz. Luego LG apareció y contactó a los redactores para que pudieran crear reseñas de productos, así como ser invitados a eventos de la compañía. Más adelante Motorola contactó al blog, HTC, Claro, Entel, HP, Huawei, Western Digital, AMD, ASUS y Samsung. Para inicios del 2015, Sync.Pe contaba con productos para revisar todos los meses, y por lo menos cuatro veces al mes, eran invitados a ceremonias de lanzamientos y conferencias de prensa. 
Pero estos no fueron los únicos resultados que provinieron de la calidad de contenidos del site, sino que estos abrieron la posibilidad de generar ciertas alianzas con marcas, o en todo caso, producir contenidos para estas bajo el estilo de la publicación.

La primera marca en acercarse a Sync.Pe para generar contenidos bajo la firma del blog fue Ripley. La compañía de retail tenía problemas al explicarle los beneficios que tenían los productos que vendían en la tienda web. Ripley acordó entregar productos para ser probados por los redactores a cambio de videos de máximo 3 minutos que vendrían ubicados en distintas secciones de su catálogo digital. Estos contenidos se apropiaban del estilo de las reseñas, pero se basaban solamente en las ventajas de los dispositivos. Sync.Pe acordó con la marca que solo recomendaría productos cuya calidad estuviera garantizada. De esta forma se produjeron una serie de videos a partir de distintos productos entre cámaras digitales, laptops, audífonos, teclados, accesorios, tablets y relojes inteligentes.

A partir del acuerdo con Ripley otras marcas se sumaron para crear contenidos independientes. Nikon y Canon se acercaron al blog con la intención de crear videos similares, pero bajo la marca de la compañía. LG, por su parte, inició conversaciones con el site para crear una serie de videos tutoriales para quienes compraron un televisor de la marca.

Finalmente, Sync.Pe fue aceptado por los organizadores del Mobile World Congress, el evento de dispositivos móviles más grande del mundo que se celebra todos los años en Barcelona. A finales de Febrero de 2016 se cubrieron los lanzamientos de Sony, LG, Huawei, HTC, Samsung, Alcatel, ZTE, entre otros. La publicación no solo accedió a estos eventos, sino a la feria en sí, donde se crearon contenidos basados en las ponencias de Mark Zuckerberg, creador de Facebook, y Jonah Peretti, fundador de Buzzfeed. Se probaron productos que todavía no habían sido lanzados al mercado, así como se experimentó con dispositivos de realidad virtual y aumentada.

Pero estos logros no solo tuvieron que ver con eventos de tecnología y productos. Los redactores de Sync.Pe también fueron invitados a participar en medios como Somos, revista semanal del diario El Comercio, que en diversas ediciones entrevistaron a los miembros del blog por sus opiniones.

Por otro lado, el prestigio logrado por los contenidos de Sync.Pe ayudaron a que Ernesto Vergara participe como expositor en el congreso "Semana FT" de Fundación Telefónica, un evento dirigido a profesores de primaria y secundaria de Trujillo e Ica, para acercarlos a utilizar la tecnología dentro de sus aulas. 
Finalmente, Coca Cola le dio a Sync.Pe un espacio dentro de su programación con mini contenidos sobre tecnología y luego con un programa en vivo semanal. El convenio con la marca duró seis meses.

La publicación también ha servido para sus creadores como una especie de reel interactivo que sirve para mostrar su trabajo. De esta forma se han conseguido clientes de manera personal que buscan los servicios de los creadores de Sync.Pe dada su experiencia. Una de las últimas experiencias de trabajar con una marca es la asesoría a la agencia Mood en la cuenta de iShop, tienda de venta oficial de Apple en el Perú.

\subsubsection{Resultados cuantitativos.}

El objetivo trazado luego de la creación de la web fue contar con tres mil visitantes únicos a tres meses después del estreno del site. Es decir, que si Sync.Pe comenzó sus operaciones en Agosto de 2013, la publicación debería contar con esa cantidad de visitantes desde Noviembre de ese año. Este resultado no fue conseguido. Desde el inicio de la web, si bien existieron meses en donde se superó ese número de usuarios únicos, jamás se pudo mantener la misma cantidad de visitantes al mes. Dependiendo de los contenidos y de las promociones en Facebook era posible llegar a picos de hasta 69 mil usuarios, como en Febrero de 2014, pero en los meses siguientes este número podía reducirse a mil o hasta menos usuarios. No se logró algo importante para cualquier tipo de publicación digital: un flujo constante de público nuevo y una cantidad de seguidores fieles a la web. 


\section{Fundamentación conceptual}

Si bien el creador de contenidos se enfrentará a múltiples decisiones previas a la construcción de un medio digital, tal como la elección de la plataforma donde realizará las publicaciones o la periodicidad de éstas; es fundamental definir primero dos conceptos que lo acompañarán en cada paso que tome hasta que el proyecto esté en marcha. Se trata, entonces, de reconocer a qué se le llama contenido y qué se considera contenido relevante.

\subsection{Sobre el contenido}

Decir que el contenido abarca todo en Internet no es ninguna exageración. De hecho, Ann Handley y C.C. Chapman (2012) en Content Rules afirman que el término engloba la inmensa mayoría de elementos que componen la web. Desde cada una de las páginas que construyen un site, como el landing page o la sección de about us, hasta las programadas para realizar funciones específicas, como formularios o carros de compra. Además, los menús, widgets y botones de navegación también son contenido en sí. Por supuesto, elementos básicos como el texto, las fotos, los gráficos, los videos, el audio y animaciones en una publicación también son considerados contenido.

Se podría afirmar entonces que el contenido es todo aquello que compone una web y que nos comunica de qué se trata, cuál es su función o funciones, y además, cómo se ordena la navegación dentro de ella.

Pero el contenido no solo aparece en las páginas web. Nuevamente en Content Rules (2012) Handley y Chapman expanden el término hacia las redes sociales. Ambos autores afirman que el contenido también es todo aquello que llega a nuestros newsfeeds, además de lo que compartimos entre nuestros amigos y seguidores. Publicaciones que no solo provienen de medios especializados en la creación de éstas, sino de los mismos usuarios que dejan su huella en internet con sus propios textos (estados, tweets, comentarios, etc.), así como con fotos, videos y audio. 


\subsection{Sobre el contenido relevante}

Si todo es contenido, el contenido relevante es aquel capaz de atraer al lector. Pero no solo eso, sino es aquel que genera reacciones por parte del usuario. En Content Rules, C.C. Chapman y Ann Handley (2012) aseguran que "el contenido relevante es todo aquel que genera engagement”. Es decir, el contenido que enciende emociones en el público, hasta el punto donde éste sienta la necesidad de destacarlo (likes en Facebook o retweets en Twitter), comentarlo, y en el mejor de los casos, compartirlo en redes sociales. De hecho, Guy Kawasaki (2014) en The Art Of Social Media afirma que el contenido relevante es "cualquier elemento de la comunicación que el lector quiera compartir”. Kawasaki (2014) va más allá y remarca

que "las visitas, los me gusta y los comentarios están bien; pero no hay nada más halagador (para un creador de contenidos) que un share". Por otro lado, Gary Vaynerchuk (2013) en Jab Jab Jab, Right Hook añade que "no es suficiente que las personas lean los artículos, es necesario lograr que se sientan tan atraídas con éstos que los propaguen”. El autor además amplía el concepto diciendo que "la definición de contenido relevante no es aquel que genera más ventas o visitas a una web, sino aquellas publicaciones que al público le interesa compartir con otros".

En resumen, el contenido relevante no solo se destaca del resto de publicaciones en una web, aplicación o red social; sino que también afecta al lector de tal manera que hace que éste reaccione. Que se sienta involucrado en él.

Kawasaki (2014) añade en The Art Of Social Media que el usuario actual de Internet, dado el alcance de las redes sociales, ha creado una suerte de reputación digital, donde todos los contenidos que comparte en la web construyen la personalidad que éste quiere dar a conocer a sus seguidores y amigos. El contenido relevante entonces es aquel que no solo genera sensaciones, sino que está construido también pensando en un público en específico. Es un usuario que, al compartir la publicación, reafirmará su personalidad digital frente al resto de usuarios conectados.

\subsection{Sobre la producción de contenido relevante}

Conseguir crear contenido relevante es el principal reto para cualquiera que pretenda crear un medio digital con éxito, una búsqueda que si bien es necesaria, alimenta la enorme competencia entre cientos de miles de sites que se disputan, click por click, la atención de un público objetivo que día a día recibe constantes estímulos visuales, sonoros e interactivos en Internet. Es por eso que dominar la producción de contenidos relevantes es clave para el éxito de una publicación, ya que podría hacer que ésta se destaque entre su competencia. A propósito 
de lo anterior, Gary Vaynerchuk (2013) en Jab, Jab, Jab, Right Hook menciona que sólo las publicaciones relevantes son capaces de "cortar a través del ruido".

En "Nobody Wants to Read Your Sh*t”, Stephen Pressfield (2016) establece algunas premisas que considera son claves para la creación de contenido relevante. En primer lugar, el contenido debe ser concentrado; es decir, que debe ser sencillo, claro y fácil de entender. Aquellas publicaciones que no cumplan con esto perderán la posibilidad de ser vistas y apreciadas. El usuario de Internet está bombardeado por mensajes y notificaciones todo el tiempo, y si es que una pieza de contenido es capaz de entregarle la información justa, sin hacerle perder el tiempo, esta publicación será revisada y tendrá más probabilidades de ser compartida. Como segunda consideración, el autor señala que el contenido relevante debe ser “divertido, sexy, interesante e informativo". No puede dejar al usuario sin una sensación u opinión a favor o en contra de él.

Chapman y Handley (2014) en The Content Rules también se aproximan a la definición de contenido relevante describiendo seis características que toda publicación de este tipo debería cumplir.

Según ambos autores todo contenido relevante tiene que ser "verdadero"; es decir, que debe estar basado en situaciones, personas, lugares y hechos reales. El lector tiene que sentirse atraído a él al verse identificado, o en todo caso, al reconocer que la realidad que el creador propone es sincera y capaz ser contrastada con otras fuentes.

La segunda característica tiene que ver con el propósito. El usuario tiene que reconocer que la pieza de contenido que le interesa tiene un objetivo de comunicación, es decir, está hecha con un fin en específico: entretener, informar, alertar, emocionar, etc.

Como tercera característica, para Handley y Chapman el contenido debe ser humano. El usuario debe ser capaz de entender que la pieza de contenido fue creada por una persona, quizás, con las mismas necesidades que él. En los blogs esto es fundamental, ya que el lector regresará a las publicaciones siempre y cuando sienta que éstas le hablan directamente. Qué han sido creadas pensando en él por alguien como él.

Ambos autores también aseguran que el contenido debe ser pasional. Los datos fríos funcionan siempre y cuando el público objetivo busque solamente información precisa, pero en la mayoría de los casos las publicaciones deben estar producidas con pasión. Que se entienda que el autor cree en lo que produce, y no solo eso, sino que los contenidos sean capaces de encender opiniones y sensaciones en el usuario. La pasión, como Handley y Chapman afirman, es contagiosa. 
Como quinta característica, los autores acuerdan que las publicaciones originales deben ser prioridad para cualquier creador de contenido. Con eso Handley y Chapman no solo quieren decir que las piezas deben ser de autoría propia, sino que incluso aquellos contenidos que son reciclados y rebotados de otros medios deben contar con un punto de vista diferente al del resto. Lograr crear una voz única, un tono de comunicación singular, y una identidad reconocible tanto a la hora de plasmar un texto, una foto, video o audio, es sin duda, uno de los principales retos para cualquier creador de contenidos digitales.

Por último, Handley y Chapman concluyen que "las mejores historias son las que incluyen el elemento de lo inesperado". El creador de contenido debe buscar crear sorpresa en el público. Incluir detalles, giros en el relato y hasta participaciones de otros bloggers que desafíen siempre las expectativas del público. El usuario sabrá recompensar estas sorpresas visitando nuevamente el site y compartiendo entre sus seguidores los contenidos que más le gustaron.

Por su parte, Chris Brogan y Julien Smith en The Impact Equation (2012) arman una fórmula a tener en cuenta a la hora de producir contenido relevante:

$$
\text { "IMPACT }=\mathrm{C} x(\mathrm{R}+\mathrm{E}+\mathrm{A}+\mathrm{T}+\mathrm{E}) "
$$

Según ellos el contenido relevante o de impacto se produce al multiplicar términos como Contraste (C), con la suma de Reach (alcance), Exposición, Articulación, Trust (confianza) y Eco.

Para Brogan y Smith (2012) el Contraste se define como en la diferenciación del contenido propio con el que exista en un site competidor. Si el autor logra diferenciarse del resto, le será más fácil que su mensaje cale en el público objetivo.

Para ambos autores Reach es otro elemento fundamental de la ecuación y se refiere al alcance. Es decir, la cantidad de seguidores que siguen al medio, tanto en redes sociales como el número de visitantes de la web. Según Brogan y Smith (2012) mientras más alto sea este número "las ideas (y contenidos) del medio digital serán más influyentes".

La Exposición también es importante, ya que "si bien el alcance es la cantidad de personas que se conectan con el medio digital, la exposición tiene que ver con la regularidad con la que el contenido del site llega al usuario”. Es decir, cuántas veces al día las publicaciones aparecen en la plataforma, red social u aplicación que vincule al público objetivo con el creador 
de contenidos. El reto, entonces, es que el contenido llegue al usuario de manera constante, pero tampoco que llegue a agotarlo.

La Articulación tiene que ver con la comprensión del mensaje. Mientras el contenido sea fácil de entender y genere sensaciones en las personas, este tendrá mayores posibilidades de destacarse del resto. Brogan y Smith (2012) afirman que "si el Contraste tiene que ver con ser visto entre muchos sites, la Articulación se basa en poder ser entendido instantáneamente".

La Confianza (Trust) es un elemento fundamental para ambos autores. Si bien un medio digital puede contar con miles de seguidores, además de tener contenidos que destaquen, que sean fáciles de entender, generen emociones y lleguen en las dosis correctas al público objetivo; sin estos pierden la confianza del usuario, de poco valdrán todos los esfuerzos que el creador de contenidos enfoque en el atractivo visual de estos. Si finalmente el autor no es capaz de decir la verdad, entonces para el público ya no valdrá la pena seguirlo.

Por último se encuentra el Eco, que como Brogen y Smith (2012) señalan es "la sensación de conexión entre el medio y lector, visitante o participante del site". El eco se genera una vez cuando los usuarios ya están habituados a los contenidos del medio, al punto mismo de convertirse en sus seguidores o fans.

Tanto Brogen como Smith (2012) concuerdan que, si bien las fórmulas y las estrategias sobre la creación de contenido digital están en constante cambio, tal como la que acaban de proponer, lo más importante siempre será el usuario. De hecho, recomiendan como fundamental, el estudio constante de los cambios de comportamiento digital del público objetivo; ya que sin estos datos, será muy difícil crear contenido relevante para éstos.

\subsection{Sobre el texto y el lector en Internet.}

Cualquier medio digital en Internet reconoce que el texto es la base de sus contenidos. Por más que en los últimos años las publicaciones audiovisuales han cobrado una mayor importancia, sobre todo en aplicaciones y en redes sociales, los textos siguen siendo fundamentales para la comunicación de blogs, páginas web y cuentas en redes sociales. Es deber del creador de contenido entender no solo su importancia, sino comprender también que el lector de Internet es distinto al de los medios tradicionales impresos. Las pantallas, el brillo de estas, y las distracciones que ofrecen las notificaciones de aplicaciones contactadas a la red hacen que el usuario pierda fácilmente la atención del mensaje basado en texto, además de sentir cansancio ocular luego de estar expuesto a estos contenidos de manera prolongada. Es por esto que se han definido ciertas reglas y consideraciones previas a la elaboración de textos 
para medios digitales cuya comunicación se dará, principalmente, en pantallas de computadoras, laptops, teléfonos inteligentes, tablets, entre otros dispositivos electrónicos.

De hecho, Handley (2014) en su libro Everybody Writes, establece que todo creador de contenido debería tener en cuenta, como primera regla, "ubicar las necesidades de la audiencia en primer lugar". Según la autora, pensar de esta forma ayuda a generar mayor contenido relevante. Handley (2014) añade que "cualquier pieza de contenido publicada por el autor debe estar hecha para satisfacer al lector". Para la autora, el reto está en producir en cada post textos concisos. Para lograrlo, estos deben cumplir con tres requisitos: ser claros, breves y útiles.

Sobre la claridad del texto, Handley (2014) afirma que el contenido relevante debería entenderse sin representar esfuerzo alguno por parte del usuario. En cuanto a la brevedad, este tipo de publicaciones deben estar construidas con el propósito de respetar el tiempo del lector. Se trata de que el texto, por más extenso que fuese, no tenga oraciones ni párrafos que no aporten en absoluto al mensaje. Por último, sobre utilidad, la autora asegura que los visitantes sabrán recompensar a una web que les demuestre que sus contenidos les ofrecen algo para sus vidas, más que solo datos fríos.

En el mismo libro, Everybody Writes, Handley (2014) ofrece ciertas consideraciones para todo creador de contenidos digitales:

- Ubicar las palabras e ideas más importantes del mensaje al comienzo de cada oración: Las primeras palabras de cada oración deberán darle al lector una primera impresión amigable, capaz de impulsarlo a seguir leyendo. Mientras menos palabras de relleno, mucho mejor para el visitante del medio digital.

- Usar un lenguaje cotidiano: el creador de contenido debe poner como prioridad un lenguaje simple y fácil de entender sobre definiciones técnicas, jerga profesional o frases rebuscadas. Mientras más natural se sienta el texto, el lector se sentirá más identificado con él.

- Priorizar la voz activa en lugar de la pasiva: los textos deben describir acciones por parte de los protagonistas del mensaje (personas, personalidades, empresas, instituciones, etc). Por ejemplo preferir "Apple lanzó dos nuevos dispositivos al mercado" en lugar de "fueron lanzados dos nuevos dispositivos de Apple al mercado".

- Usar verbos fuertes en lugar de verbos débiles: los textos digitales tienen poco tiempo y muchas distracciones con las qué luchar para generar un impacto en el lector, es por 
eso que es recomendable que cada oración genere el mayor impacto posible. Por ejemplo, preferir "el calor que emana el cuerpo del smartphone produce incomodidad" a "el calor que sale del cuerpo de aluminio da incomodidad".

- No usar ciertos adverbios: palabras como "normalmente", "curiosamente", “instantáneamente” o adverbios similares debían ser descartados al restarle fuerza a las oraciones, además de alargarlas. Por ejemplo, preferir "Samsung perdió de inmediato la confianza de millones de usuarios por culpa del Galaxy Note 7" en lugar de "Samsung perdió inmediatamente la confianza de millones de usuarios por culpa del Galaxy Note 7".

- No usar clichés: Aunque pueden sonar naturales, debido a la gran cantidad de veces que el lector está expuesto a ellos, lo cierto es que nada ocupa más espacio adicional y resta creatividad que frases o dichos conocidos. Preferir "Sony anunció una nueva versión de su actual consola: el Playstation 4 Pro" en lugar de "El día de hoy Sony anunció una nueva versión de su actual consola: el Playstation 4 Pro”.

Aunque Handley (2014) recomienda en Everybody Writes respetar la gran mayoría de reglas de redacción generales, sugiere pasar por alto algunas con la intención de facilitar la lectura del usuario de Internet:

- No es un error comenzar un párrafo o una oración con "y", "porque", "pero": si bien es algo que no se permitiría en un texto académico, en una publicación de un medio digital hacerlo aporta energía. Por ejemplo, “Al presionar un icono en la pantalla del iPhone 6S se activa la función 3D Touch, que abre diversas opciones y atajos que antes se encontraban dentro de la aplicación. Y si lo hacemos con la misma fuerza sobre un link en Safari, tendremos un vistazo previo de los contenidos de esa página sin tener que abrirla en otra pantalla".

- Se permite fragmentar oraciones: Mientras más cortas sean, será más fácil para el lector digerirlas. Es por eso que cortar oraciones no es un pecado para el creador de contenidos digitales, en especial si de generar ritmo se refiere. Por ejemplo "El nuevo Moto X es impresionante. Es rápido. Se ve bien. La pantalla es grande. La cámara es decente. Pero sobretodo, trae un precio que les hará dudar si no me equivoqué al escribirlo". 
- Los párrafos pueden estar hechos a partir de una sola oración: el lector de Internet aprecia tanto la información confiable, como los espacios en blanco para que sus ojos descansen. Es por eso que las oraciones y los párrafos no solo deberían ser cortos, sino que los espacios entre ellos deberían ser los más amplios posibles. Por ejemplo: "LG creó un teléfono no solo con el último Galaxy S de Samsung en la mira, también buscó reivindicar años de desinterés por un público que siempre prefirió la competencia. Si pensaron que LG era sólo era una marca de televisores, ahora podrán comerse sus palabras".

En resumen, el texto para una publicación en internet es la forma más básica que existe para conectarse con sus usuarios, pero no por eso la que menos se debe tener en cuenta, sobre todo luego de la explosión de contenidos gráficos y audiovisuales. Si un medio digital es capaz de atraer y cautivar a su público objetivo a través de oraciones, párrafos y espacios de descanso, crear otros tipos de contenidos será mucho más sencillo.

\subsection{Sobre los contenidos gráficos y audiovisuales.}

Con el avance de Internet, tanto en la cantidad de dispositivos que pueden conectarse a él, así como la penetración del servicio móvil y casero, además del incremento constante en el ancho de banda y la velocidad, los contenidos basados en texto han cedido en popularidad por otros que aprovechan estas nuevas facultades de conexión.

En el libro The Power of Visual Storytelling, Ekaterina Walter y Jessica Gioglio (2014) afirman que gracias a estos cambios, así como la proliferación de redes sociales como Instagram, Pinterest y Facebook, la frase "una imagen vale más que mil palabras" está más vigente que nunca. Según ambas autoras, tanto expertos en marketing como creadores de contenidos enfocan sus esfuerzos en publicaciones gráficas y audiovisuales, esto con el fin de amplificar la atracción e interacción del público objetivo. De hecho, Walter y Gioglio (2014) señalan que desde el 2013 "las publicaciones que cuentan con fotografías o álbumes reciben entre 120 a $180 \%$ más interacción del usuario que aquellos contenidos basados en texto". Además, que las compañías y medios que han optado por producir piezas de este tipo se han vuelto líderes de sus categorías, "siendo recompensados con engagement, tráfico de visitas y hasta ventas". Para Walter y Gioglio (2014) ahora existe un nuevo término entre los medios digitales: la narrativa visual. Este concepto se define como "el uso de imágenes, videos, infografías, presentaciones y otros recursos visuales en medios digitales o en redes sociales, 
con la intención crear historias gráficas que se apoyen en los valores de una marca o una publicación de Internet”.

Walter y Gioglio realizaron una serie de estudios en 2013 que arrojaron estadísticas con las que fundamentan la explosión de los contenidos gráficos y audiovisuales en Internet. Las autoras encontraron que:

- El 90\% de la información transmitida al cerebro es visual y las imágenes son procesadas sesenta mil veces más rápido que el texto.

- El $40 \%$ de personas encuestadas reaccionó mejor a información visual que a contenidos con solo texto.

- El periodo de atención del adulto promedio es de 2.8 a 8 segundos.

- El 94\% de los contenidos que recibieron atención por parte de los usuarios de Internet tenían imágenes atractivas sobre publicaciones sin gráficos.

- $67 \%$ de consumidores de productos opinaron que se guiaban más por imágenes y videos que por contenidos descriptivos basados en textos.

- En un estudio de 739000 tweets, el 76\% de estos fueron compartidos porque traían una foto anexada y el $18 \%$ de estos porque incluían un video.

- Los contenidos en Facebook con fotografías aumentaban un 37\% el engagement con el público objetivo.

- El $46.1 \%$ de personas piensa que una página web ofrece credibilidad a partir de su diseño.

- Publicaciones que incluyen videos atraen tres veces más visitantes que los que solo están basados en texto.

- El 85\% de personas está más dispuesta a adquirir un producto luego de ver un video demostrativo de este en Internet.

De todos modos, para ambas autoras, no solo basta con producir contenidos audiovisuales o gráficos para atraer a la audiencia, sino que estos contenidos deben basarse en una estrategia definida, y por supuesto, en los valores y el estilo visual que propone el medio digital.

\subsection{Sobre el tono de comunicación y estilo}


Dominar la creación de contenido relevante, tanto en textos como en gráficos y textos puede ser de gran ayuda para un medio digital, encontrar un tono de comunicación y un estilo es lo que terminará por hacer que el medio se destaque de otros.

Ann Handley (2014) define el tono como la perspectiva y punto de vista de una publicación sobre el tema o los temas tratados en sus contenidos. La autora asegura además que la voz es la expresión de la personalidad del site. Esta personalidad puede estar expresada por palabras, sonidos, gráficos y contenidos audiovisuales que diferencian al medio de su competencia directa. Si bien un medio digital puede tratar los mismos temas que otro, y hasta emitir publicaciones similares, como el caso de notas informativas o reseñas del mismo dispositivo tecnológico, es la forma y el punto de vista particular el que diferenciará los contenidos de un site al otro. El tono de comunicación y el estilo son partes fundamentales en el momento de crear contenido relevante, sobre todo cuando la competencia también es capaz de generar engagement con sus lectores o cuenta con una gran cantidad de ellos.

Para encontrar la voz y el tono único de la publicación Handley (2014) recomienda que el creador de contenidos investigue tanto al público como a sí mismo. Que encuentre el cruce entre los intereses de sus lectores y los valores de su marca o publicación. Para la autora, además, el estilo y la voz propia de la web no solo tiene que ver con el texto, foto, audio o video, sino también con el diseño general del site. Si todo los contenidos comunican, entonces cada pieza que compone el blog o página web debe ser creado para afianzar la personalidad y el tono de comunicación. Cada detalle, como los menús, los títulos, la página de about us, de contacto, de error, entre otras deben estar producidas con el fin de dejar en claro, no solo de qué trata la publicación, sino también del humor, seriedad, lenguaje, jerga o intenciones de ésta.

El tono de comunicación no solo repercute en el diseño de los contenidos de la web, sino también debe percibirse en las redes sociales y aplicaciones relacionadas al site. No solo eso, sino también debe existir en cada tipo de situación que los administradores de esta tengan que enfrentar. Si una web prioriza un tono divertido, casual y hasta irreverente, los creadores de contenidos encargados de ésta deberán saber modular la voz de la publicación incluso en situaciones críticas, como pedir disculpas a sus usuarios o al responder los ataques de la competencia, si así se diera el caso. 


\section{Lecciones aprendidas.}

Sync.Pe dejó de funcionar en Mayo de 2016 luego de aproximadamente tres años de funciones. La publicación había conseguido cierto prestigio entre los medios digitales, que veían al blog como un modelo a imitar. La llegada del site a la oferta local de páginas especializadas de tecnología significó un cambio. Webs como Perúsmart, además del blog y luego canal de Youtube de Jesus Véliz invirtieron en nuevos equipos, modificaron sus logos y hasta cambiaron el diseño general de sus páginas. Los videos, textos y otros contenidos generados por estas publicaciones intentaron mejorar de calidad, y hasta copiaron ciertos detalles de los contenidos que podían encontrarse en la página.

Lo cierto es que, a pesar del cuidado en cuanto a la creación de contenidos, Sync.Pe no fue un site exitoso en cuanto a visitas. Los objetivos no se lograron, no se consiguió generar una comunidad, y aunque existieron fans que hasta participaron en algún momento como redactores del blog, ninguno de ellos se mantuvo por más de algunos posts. Esto perjudicó a Sync.Pe porque finalmente, si bien es fundamental que los contenidos de una publicación tengan la mejor calidad posible, los números y la cantidad de interacciones siempre serán importantes también. Sobre todo en un medio en donde los likes, la cantidad de seguidores y el número de comentarios puede ser, para una marca o institución, un indicador mucho más poderoso que la misma calidad del texto, la fotografía y los videos. Al no poder demostrar que se contaba con un número de seguidores constante, en crecimiento y dispuesto a participar y compartir los contenidos, las marcas relegaron a la publicación entregando los dispositivos para prueba tarde, y mucho después de publicaciones con más usuarios. De esta forma, el site perdió oportunidades de emitir reseñas en el tiempo exacto al lanzamiento de los productos. Cada vez era más difícil ser el blog que ayude al público a decidir una compra. Al no producir contenido propio el site tuvo que reemplazar estos contenidos por noticias que también eran compartidas por otras páginas. El público que quedaba de Sync.Pe perdió el interés. Sus creadores también. 
A continuación se presentan reflexiones que exploran y explican en qué acertó, en qué se falló, y cómo se podría haber mejorado el trabajo de creación de contenidos en Sync.Pe.

\subsection{Aciertos.}

Los logros conseguidos por la publicación tuvieron que ver, sin duda alguna, a la calidad de sus contenidos. Desde la creación del logo hasta la definición de un estilo visual, Sync.Pe consiguió lo que hasta ese momento no habían logrado páginas similares en la oferta local: una identidad visual que atravesara el diseño de la web, así como todo el resto de los elementos gráficos y audiovisuales. De hecho, se creó un estándar de contenidos capaces de replicarse según la plataforma. El mismo tono de comunicación que se encontraba en los textos se encontraba también en la locución de las reseñas, el programa en vivo y las intervenciones en prensa. Se definieron, además, reglas de creación de contenido que aseguraban que la calidad de las publicaciones sea constante, e incluso, que mejorara con el tiempo.

Además, en apenas cuatro meses de iniciadas las operaciones del blog, empresas como Sony y LG se vieron interesadas en contar con Sync.Pe entre los medios que convocaban a eventos, así como a los que les confiaban productos de prueba. Esto no se hubiera dado de esta forma si no fuera por la calidad de los contenidos que los representantes de estas marcas descubrieron en Sync.Pe. Por otro lado, Ripley, Nikon, Canon, LG y Coca Cola quedaron convencidos de las capacidades de realización de los creadores del blog, a los que les encargaron materiales exclusivos bajo el nombre de la publicación o de la misma marca. De todos los sites de tecnología del país, fue Sync.Pe el único site preferido por Coca Cola para la producción de piezas de audio y un programa en vivo.

\subsection{Fallas.}

Aunque existió una investigación profunda del público objetivo, muy pocos de estos datos se aprovecharon en realidad para la creación de contenidos y diseño de la página. La gran mayoría de usuarios que visitaba el site lo hacían desde smartphones, y aunque la web era responsive y se acomodaba bien a cada pantalla, los contenidos siempre fueron pensados para verse en pantallas más grandes, con textos ordenados a partir de columnas, con fotos en tamaño grande y una extensión de texto que no era la adecuada para la lectura en teléfonos inteligentes. Es por eso que muchos usuarios solo se quedaban un momento en la web, se 
cansaban de leer los contenidos y salían de ella. Además, no se establecieron metas y objetivos a mediano y largo plazo con respecto al público.

Por otro lado, no existió una estrategia digital tanto para los objetivos como para la promoción de Sync.Pe como web. Si bien existió pauta en Facebook para promocionar la cuenta en esa red social, así como los contenidos del blog, nunca fue constante ni con algún tipo de objetivo en específico. El proyecto solo crecía en seguidores cuando se invertía en ello, pero el crecimiento orgánico era nulo.

No se aprovecharon otras redes sociales. Se dedicaron todos los esfuerzos en Facebook, y si bien se trató compartir contenidos en Twitter y se abrió una cuenta en Instagram, estas dos últimas aplicaciones eran apenas usadas. En Facebook, además, solo se compartían contenidos del blog y no se crearon publicaciones exclusivas para esta plataforma. Youtube, por otro lado, no se explotó como se hubiese podido. Los mejores contenidos creados por la publicación fueron en video, pero rara vez estos eran introducidos en el canal, que en tres años de funcionamiento apenas superó los 300 suscriptores.

Se estableció una parrilla de contenidos distintos para crear variedad en la oferta de publicaciones del site, pero esto nunca se puso en práctica. La gran parte de contenidos compartidos por Sync.Pe eran noticias que podían verse también en otros medios. Estas piezas fueron escritas bajo el estilo y tono de comunicación de la página, pero definitivamente no era contenido exclusivo capaz de sorprender y darle valor agregado al usuario. Las reseñas se producían muy de vez en cuando, mientras que reportajes, artículos, comparaciones y otros o aparecieron pocas veces a jamás se produjeron.

No se estableció una estrategia de seguimiento de métricas. Si bien se instalaron las aplicaciones correspondientes de Google Analytics, además de contar con los servicios de Alexa para monitorear el tráfico del site, muy poco o nada se hizo con esta información. Se tomaron como datos importantes el número de visitantes únicos por mes, pero no otros como de dónde provenían exactamente las visitas, desde qué dispositivos, desde qué sistemas operativos y tampoco se midió el éxito real de las reseñas en el público más allá de un tema visual, sino de fondo.

No se pudo conservar la participación de nuevos redactores. Aunque existió una convocatoria, y por otro lado, algunos se incorporaron al site, estos solo contribuyeron con muy pocos contenidos, no de forma constante, y además, dejaron de hacerlo al no existir algún tipo de beneficio económico, ya que Sync.Pe nunca generó dinero como proyecto al no vender espacios para publicidad. 
Los contenidos fueron creados para satisfacer a la redacción y no a las necesidades del público. Las reseñas, con el fin de demostrar las capacidades de producción de Sync.Pe, tenían entre 25 a 30 fotos en promedio, un video de más de 6 minutos y por lo menos 2500 palabras de texto. A pesar de ofrecer una buena calidad, al usuario de Internet le tomaba demasiado tiempo de lectura. Muchos preferían ver sólo los videos, otros abandonaban el post asustados por la cantidad de texto.

No se generó una optimización en el trabajo de contenidos. Cada reseña tomaba de 12 a 13 horas de realización, entre la creación del texto, la realización de las fotos y videos, la edición de estos materiales, la diagramación en Wordpress y la promoción de las piezas en redes sociales. Por otro lado, solo una persona se encargaba de la producción y promoción de contenidos, lo que hacía de esto una actividad que desgastaba al personal.

No se le dio la importancia suficiente a la competencia. Aunque se investigó sobre ésta las conclusiones apenas abordaron los números de vistas y de seguidores, pero no lo que sí funcionaba dentro de sus contenidos. Se pensó que contar con contenidos de calidad era suficiente para llamar la atención del público, y si bien esto funcionó en un principio, no estableció una comunidad entre el site y los lectores. Proceso que sí había logrado la competencia. Mientras Sync.Pe sumaba usuarios lentamente, pero se enfocaba en producir cada vez mejores publicaciones, la competencia mejoró ligeramente la cantidad de los suyos, pero incrementó considerablemente las visitas y seguidores.

\subsection{Autocrítica.}

A partir de lo revisado, tanto en los logros como en lo que no se pudo conseguir en Sync.Pe, se aprendió que se debieron tener en cuenta las siguientes recomendaciones:

\subsubsection{Establecer, desde un comienzo, objetivos fundamentados.}

Conseguir tres mil visitantes en un mes es un logro que, cómo tal, puede ser sonar interesante para un blog que recién inicia. Pero sin tener en cuenta a qué equivalen esa cantidad de visitantes, los números pasan a ser solo datos fríos sin mucho significado. Se aprendió que los objetivos no solo deben estar basados en metas, indicadores de éxito y métricas establecidas para leer sus resultados, sino que deben tener un porqué. En el caso de los tres mil seguidores únicos hubiese sido útil, por ejemplo, definir a qué equivale ese número en cuanto a creación 
de comunidad, para fines publicitarios, como indicador de éxito o fracaso de algún tipo de contenido, etc. En cambio, el objetivo de conseguir la atención de marcas tecnológicas, a partir de la producción contenidos relevantes, fue una meta con una intención detrás: que Sync.Pe sea convocado a eventos, conferencias de prensa, lanzamientos de productos, además, que estos fueran prestados para realizar reseñas. Este objetivo tuvo desde el comienzo una razón de ser, y fue la de crear contenido exclusivo a partir de estos acuerdos; contenidos que harían que finalmente la publicación se destaque de las demás. De ambos objetivos, solo el que tuvo fundamento fue el que se cumplió.

\subsubsection{Plantear nuevos objetivos a partir de los ya alcanzados:}

De todos modos, aunque se llamó la atención de las marcas relativamente temprano en la vida del blog, hubiera sido recomendable establecer nuevos objetivos con ellas una vez cumplida la meta principal. Es decir que, una vez establecido el nexo con los representantes de estas compañías en el país, era fundamental definir objetivos que apunten a lograr mayores avances con ellas. Además, definir qué indicadores (likes, número de visitas al mes, comentarios, shares, etc.) eran indispensables para que las marcas, no solo tengan en cuenta un medio digital, sino que a este le den prioridad por encima del resto en cuanto a exclusivas y prestamos de productos. Sync.Pe, si bien entregó contenidos de una calidad superior a su competencia, jamás perteneció a la élite de los blogs de tecnología locales ya que a pesar de que fue un deseo, nunca se fijó como un objetivo.

\subsubsection{La importancia de un calendario editorial.}

Sobre los mismos contenidos, una estrategia específica para las publicaciones hubiera solucionado varios problemas que sucedieron dentro de Sync.Pe. Por ejemplo, dentro de esta estrategia de contenidos se pudo elaborar un calendario editorial. Este tipo de documento es básico para ordenar las publicaciones en un esquema semanal y mensual. Existiendo distintos tipos de contenidos (noticias, reseñas, artículos, etc.) establecer un orden de entregas pudo generar una costumbre en el público de esperar posts específicos por día, por semana y por mes. Además, un calendario editorial ayuda a generar un esquema visual de cómo están repartidos los contenidos y qué nuevas publicaciones podrían agregarse para sorprender siempre al lector. Además de ayudar a mantener continuidad al momento de publicar. Un 
modelo similar a este hubiese cambiado, sin duda alguna, la forma de crear y manejar contenido para el blog.

\subsubsection{La importancia de una estrategia de promoción en redes sociales.}

Si bien existieron intentos de crear campañas digitales para promocionar el blog, una verdadera estrategia de promoción de contenidos en Facebook hubiese ayudado definitivamente a conseguir más seguidores, además, a que las publicaciones del site sean conocidas por más personas interesadas en páginas de tecnología. Definir, en primer lugar, un presupuesto semanal y una lista de contenidos a promocionar. Si los artículos y las reseñas eran las publicaciones más importantes, y todas ellas podían producirse semanalmente, entonces crear una pauta a partir del lanzamiento de estas publicaciones hubiese ayudado a despertar el interés del público. Esta estrategia, además, debería contar con indicadores de éxito establecidos para fundamentar el retorno de inversión de la pauta publicitaria. Es así cómo se sabría si la promoción tiene el efecto esperado.

\subsubsection{Contenidos líquidos.}

Se pudieron aprovechar más las distintas plataformas digitales con las que contaba Sync.Pe. Una estrategia de publicación hubiese logrado que cada contenido de la web se multiplique en cuanto a su extensión y posibilidades de ser visto, comentado y compartido. Una reseña, por ejemplo, pudo tener una versión propia para Facebook, Twitter, o en todo caso, en Instagram o Snapchat. De esta forma, el público que prefiere no salir de sus aplicaciones preferidas, tendría contenidos de Sync.Pe moldeados para cada una de éstas. No solo eso, sino que producir contenidos exclusivos para estas plataformas hubiera hecho que se consiguieran más seguidores, y los ya convertidos, se mantuvieran fieles a la publicación.

\subsubsection{La importancia de conocer al usuario.}

Si bien existió un gran interés por definir al público objetivo de Sync.Pe, mucho de lo que se supo de él provino de estudios cuyo mayor valor era el cuantitativo. Para tener una visión mucho más clara del "techie" peruano, hubieran sido necesarios focus groups y entrevistas a profundidad con personas que frecuentaran blogs de tecnología, tanto locales 
como internacionales. De esta forma se hubiese contado con datos importantes sobre cuáles son los tipos de contenido que el público realmente quería ver, qué es lo que los hace conectarse con sites similares. y sobre todo, cuáles son los factores que los conectan a ellos. En otras palabras, cómo se generan comunidades digitales a partir de los contenidos de un blog. Por ejemplo, el público fanático de la tecnología consume contenidos digitales cada vez más en dispositivos móviles, y sobre todo, en formato de video. Aumentar la cantidad de publicaciones más fáciles de leer en pantallas pequeñas, así como la producción de contenidos audiovisuales hubiesen hecho que Sync.Pe se amoldara mejor a las necesidades de sus lectores. Estos datos hubiesen sido fundamentales para que Sync.Pe consiguiera un público cautivo.

\subsubsection{La importancia de los medios tradicionales.}

Se pudo aprovechar mucho más, por ejemplo, las intervenciones que tuvo la web en medios escritos como Somos, suplemento semanal del diario El Comercio y considerada como la revista más leída del país. Por ejemplo, se pudo promocionar previamente la participación del blog en esta revista entre el público, pero sobre todo, entre las marcas que siempre buscan conectarse con páginas de tecnología prestigiosas. Además se pudieron establecer estrategias que tuvieran que ver con la aparición del site en otros medios tradicionales: artículos colaborativos con revistas especializadas o incluso hasta contenidos creados para televisión, como entrevistas. Si bien sí se aprovechó el programa en vivo en Coca Cola FM para generar mayor atención de las marcas, no fueron muchas las que conocieron sobre este espacio. Lo mismo ocurrió tanto con el público objetivo y los que ya eran seguidores de Sync.Pe, que apenas conocieron del show.

\subsubsection{Conocer mejor a la competencia:}

Un estudio a consciencia de sites similares hubiese sido fundamental para generar estrategias basadas en qué es lo que funciona y qué se podría mejorar en estas páginas. Es cierto que los contenidos de estos blogs eran revisados continuamente, pero esos datos recogidos no construyeron ni estrategias ni modificaron de alguna forma las publicaciones de Sync.Pe. Si bien los contenidos del site eran superiores en calidad, la competencia siempre tuvo como principal ventaja haber conseguido crear comunidades digitales. Arturo Goga, por ejemplo, ya tenía construida una base de lectores fieles, además del prestigio de ser el blogger más 
importante de tecnología en el Perú, gracias a apariciones en medios tradicionales como programas de televisión, periódicos y columnas propias en medios impresos. Por otro lado, el canal de YouTube de Jesus Veliz comenzó a multiplicar sus seguidores cuando el autor decidió enfocarse únicamente en la producción de video, ofreciendo contenidos todas las semanas y con temáticas especiales; por ejemplo "Smartes", donde un día a la semana el conductor recomendaba aplicaciones y otros trucos para los usuarios de dispositivos inteligentes. Perusmart, la página web de tecnología con más interacción del país, aprovechó la cantidad de seguidores en redes sociales con la que cuentan, 130 mil likes aproximadamente, para conseguir contenidos exclusivos con marcas, como contar con productos semanas antes que otros blogs, crear concursos y lanzar los "Premios Perusmart" a los mejores productos del año; premiación que las mismas marcas promocionaban en redes sociales.

En resumen, si bien los contenidos de Sync.Pe fueron el elemento de la comunicación mejor logrado en el site, esto le restó atención a otros aspectos del mantenimiento de un medio digital. Existió un gran esfuerzo porque los textos, fotos, gráficos, audio y video tuviesen una calidad que sorprendiera al público, a la competencia y a las marcas; no se generaron estrategias para promocionarlos de una forma inteligente. Para que las publicaciones no solo generaran picos de visitas, dependiendo de la coyuntura o información compartida, sino que establezcan con el tiempo una comunidad de lectores fieles a la publicación; que es lo más importante que puede tener un blog, una cuenta en alguna red social o un canal de Youtube. 


\section{Referencias}

- Ann Handley. (2014). Everybody Writes. EEUU: Wiley.

- Ann Handley, C.C. Chapman. (2012). Content Rules: How to Create Killer Blogs, Podcasts, Videos, Ebooks, Webinars (and More) That Engage Customers and Ignite Your Business. EEUU: Wiley.

- Alfred Hermida. (2014). Tell Everyone: Why We Share and Why It Matters. EEUU: Doubleday Canada.

- Michael Hyatt. (2012). Platform: Get Noticed in a Noisy World. EEUU: Thomas Nelson.

- Guy Kawasaki, Peg Fitzpatrick. (2014). The Art Of Social Media. EEUU: Portfolio.

- Dave Kerpen. (2012). Likable Social Media. EEUU: McGraw-Hill.

- Austin Kleon. (2012). Steal Like An Artist. EEUU: Workman Publishing Company.

- Jonah Sachs. (2012). Winning The Story Wars: Why Those Who Tell (and Live) the Best Stories Will Rule the Future. EEUU: Harvard Business Review.

- Robert Scoble. (2014). Age Of Context. EEUU: Patrick Brewster Press.

- Gary Vaynerchuk. (2013). Jab, Jab, Jab, Right Hook: How to Tell Your Story in a Noisy Social World. EEUU: HarperBusiness.

- Ekaterina Walter, Jessica Gioglio. (2014). The Power Of Visual Storytelling: How to Use Visuals, Videos, and Social Media to Market Your Brand. EEUU: McGraw-Hill Education. 